\title{
REVIEW OF THE ACTUALISTIC TAPHONOMY OF SMALL MAMMALS INGESTED BY SOUTH AMERICAN PREDATORS. ITS IMPORTANCE IN THE INTERPRETATION OF THE FOSSIL RECORD
}

\footnotetext{
${ }^{1}$ Facultad de Ciencias Exactas y Naturales, Universidad Nacional de La Pampa. Uruguay 151, L6300CLB Santa Rosa, La Pampa, Argentina. ${ }^{2}$ Cátedra de Anatomía Comparada, Facultad de Ciencias Naturales y Museo, Universidad Nacional de La Plata. Calle 64 s/n, B1900AMC La Plata, Buenos Aires, Argentina.

${ }^{3}$ Consejo Nacional de Investigaciones Científicas y Tecnológicas (CONICET).

${ }^{4}$ Grupo de Estudios en Arqueometría (GEA), Facultad de Ingeniería, Universidad de Buenos Aires. Av. Paseo Colón 850, C1063ACV Ciudad Autónoma de Buenos Aires, Argentina.
}

Recibido: 13 de octubre de 2018 - Aceptado: 11 de marzo de 2019

Para citar este artículo: Claudia I. Montalvo, and Fernando J. Fernández (2019). Review of the actualistic taphonomy of small mammals ingested by South American predators. Its importance in the interpretation of the fossil record. Publicación Electrónica de la Asociación Paleontológica Argentina 19 (1): 18-46.

Link a este artículo: http://dx.doi.org/10.5710/PEAPA.11.03.2019.275

DESPLAZARSE HACIA ABAJO PARA ACCEDER AL ARTÍCULO

Otros artículos en Publicación Electrónica de la APA 18(1):

\section{Aldo R. Prieto}

HISTORIA DE LA PALINOLOGÍA DEL CUATERNARIO EN LA ARGENTINA: UNA RESEÑA A 90 AÑOS DE SUS COMIENZOS

\section{Virginia Mancini et al.}

ANÁLISIS Y MÉTODOS PALEOECOLÓGICOS PARA LA RECONSTRUCCIÓN DE COMUNIDADES DE BOSQUE Y ESTEPAS DE PATAGONIA, ARGENTINA
Asociación Paleontológica Argentina Maipú $6451^{\circ}$ piso, C1006ACG, Buenos Aires República Argentina Tel/Fax (54-11) 4326-7563 Web: www.apaleontologica.org.ar

\section{Dominique Mourelle et al.}

ANÁLISIS PALINOLÓGICO ACTUAL Y DEL CUATERNARIO TARDÍO EN LA REGIÓN DE LOS CAMPOS (URUGUAY Y SUR DE BRASIL): ESTADO DE LAS INVESTIGACIONES, DIFICULTADES Y POTENCIALIDADES 


\title{
REVIEW OF THE ACTUALISTIC TAPHONOMY OF SMALL MAMMALS INGESTED BY SOUTH AMERICAN PREDATORS. ITS IMPORTANCE IN THE INTERPRETATION OF THE FOSSIL RECORD
}

\author{
CLAUDIA I. MONTALVO1, AND FERNANDO J. FERNÁNDEZ2,3,4
}

1Facultad de Ciencias Exactas y Naturales, Universidad Nacional de La Pampa. Uruguay 151, L6300CLB Santa Rosa, La Pampa, Argentina. cmontalvo@exactas.unlpam.edu.ar

2Cátedra de Anatomía Comparada, Facultad de Ciencias Naturales y Museo, Universidad Nacional de La Plata. Calle 64 s/n, B1900AMC La Plata, Buenos Aires, Argentina.fernandezf77@yahoo.com.ar

${ }^{3}$ Consejo Nacional de Investigaciones Científicas y Tecnológicas (CONICET).

${ }^{4}$ Grupo de Estudios en Arqueometría (GEA), Facultad de Ingeniería, Universidad de Buenos Aires. Av. Paseo Colón 850, C1063ACV Ciudad Autónoma de Buenos Aires, Argentina.

\begin{abstract}
In this paper, the current state of knowledge of the taphonomic characteristics of micromammal (rodents and marsupials) remains generated by the action of the different predators (avian raptors and carnivore mammals) of South America (particularly of Argentina), known through actualistic studies, is reviewed. The analyzed taphonomic attributes enabled the adjustment, by means of extensive comparisons among different groups of predators and prey, of the modification categories indicated in the original papers. The data herein revised and assessed suggest that the evaluated South American predators may be grouped into four categories of modification: a) Light (Tyto alba, Bubo virginianus, Strix chacoensis and Asio flammeus); b) Moderate (Athene cunicularia, Geranoaetus melanoleucus, Geranoaetus polyosoma and Pseudoscops clamator); c) Heavy (Circus buffoni, Caracara plancus, Elanus leucurus, Didelphis albiventris, Leopardus geoffroyi and Lontra longicaudis); d) Extreme (Milvago chimango, Puma concolor, Puma yagouaroundi, Conepatus chinga and Lycalopex griseus). Finally, the research herein discussed evaluates how these studies were applied in the fossil record of both palaeontological and archaeological sites of South America.
\end{abstract}

Key words. Bone modifications. Neotaphonomy. Micromammals. Predators. Actualistic analogous. Argentina.

Resumen. REVISIÓN DE LA TAFONOMÍA ACTUALÍSTICA DE LOS MICROMAMÍFEROS INGERIDOS POR DEPREDADORES DE AMÉRICA DEL SUR. SU IMPORTANCIA EN LA INTERPRETACIÓN DEL REGISTRO FÓSIL. En este trabajo se valora el estado actual del conocimiento de las características tafonómicas de los restos de micromamíferos (roedores y marsupiales) generados por la acción de los diferentes depredadores (aves rapaces y mamíferos carnívoros) de América del Sur (particularmente de Argentina), a través de la revisión de los estudios actualísticos. Los atributos tafonómicos analizados permitieron ajustar, a través de comparaciones extensas entre los diferentes grupos de depredadores y presas, las categorías de modificación indicadas en los artículos originales. La información revisada sugiere que los depredadores de América del Sur evaluados pueden agruparse en cuatro categorías de modificación: a) Ligera (Tyto alba, Bubo virginianus, Strix chacoensis y Asio flammeus); b) Moderada (Athene cunicularia, Geranoaetus melanoleucus, Geranoaetus polyosoma y Pseudoscops clamator); c) Fuerte (Circus buffoni, Caracara plancus, Elanus leucurus, Didelphis albiventris, Leopardus geoffroyi y Lontra longicaudis); d) Extrema (Milvago chimango, Puma concolor, Puma yagouaroundi, Conepatus chinga y Lycalopex griseus). Finalmente, se evalúa cómo estos estudios se aplicaron al registro zooarqueológico y paleontológico de América del Sur.

Palabras clave. Modificaciones óseas. Neotafonomía. Micromamíferos. Depredadores. Análogos actuales. Argentina.

THE SMALL mammal assemblages constitute a particular part of the fossil record identified as a group consisting of mammals of less than $5 \mathrm{~kg}$ in weight (Andrews, 1990). Neogene and Quaternary micromammal assemblages are well represented throughout all South America; however, most related studies have focused on the Southern Cone (Saavedra, 1994; Pardiñas and Galliari, 1998; Pardiñas, 1999b, 2004;
Ortiz, 2001; Quintana, 2001, 2016a,b; Pardiñas et al., 2002; Saavedra and Simonetti, 2003; Montalvo et al., 2008a,b, 2016c, 2017; Rodrigues, 2008; Verzi et al., 2008; Fernández et al., 2009a, 2012, 2015, 2016a,b; Deschamps et al., 2012; Fernández, 2012; Salemme et al., 2012; Pokines, 2014; Andrade, 2015; Torres et al., 2015; Hadler et al., 2016; Kerber et al., 2017; Stutz et al., 2017; Fernández and Pardiñas, 2018). 
In addition to addressing taxonomic and phylogenetic issues, it is interesting to explain the mechanisms that intervened in the production of these fossil assemblages since this would allow us to adjust the interval of their formation and thus formulate more precise palaeoecological interpretations (e.g., Andrews, 1995). Andrews (1990) designated the biological agents as responsible for many of the biases that can be identified in fossil assemblages although he did not rule out the importance of other factors linked with the nature of the bearing levels in which the remains were found. It is essential to remark that the sedimentary context of the fossil bearing levels must be known. Even though, in this case, we only attempt to investigate the ways in which we are enabled to explain the history of fossil small mammal assemblages of biological origin, the sedimentary context is very important when interpreting its taphonomic history.

Predators are the main accumulator agents of bone remains of small vertebrates (e.g., Mellet, 1974; Andrews, 1990; Fernández-Jalvo et al., 2016; Fernández et al., 2017). On this basis, the actualistic assessments that analyze the modifications produced by predators to the bones of their prey constitute good tools to use as analogues to contribute in the interpretation of the characteristics of fossil assemblages. Within the diversity of predators and prey, we intend to find the possible biological explanations to the processes acting in the accumulations that can be recovered in the fossil record. It is only by recognizing the problems of current predators that it is possible to know if actualistic taphonomic evaluations can be used as analogues to understand what happened in the record (Andrews, 1990; Fernández and Montalvo, 2017). The processes which occurred at the time of death and very close to it (biostratinomic processes) can be interpreted through the attributes preserved in the remains, which are, in turn, those which could somehow be explained by the actions of predators. In this context, actualistic taphonomic evaluations have turned into good comparative tools (Andrews, 1990; Denys, 2011).

In this paper the current state of knowledge regarding the taphonomic characteristics of micromammal assemblages generated by the action of the different predators of South America (particularly of Argentina), known through actualistic studies, is reviewed. Comparisons between different groups of predators and prey are herein drawn. Finally, the ways in which these studies were applied in fossil (both archaeological and palaeontological) sites of South America are hereby pondered.

\section{Current status of the taphonomy of small mammals}

Among the accumulating agents, the action of predators produces identifiable faunal associations according to the characteristics that each one prints on the bone assemblages that they generate. In this sense, the bone accumulations of current mammals (and of other vertebrates to a lesser extent) recovered from pellets and scats produced by different predators were evaluated from a taphonomic point of view. The action of each predator and the consequent modifications can be compared with those of other predators in order to explain the origin of the accumulations in the record.

There are numerous papers on actualistic studies for the northern hemisphere; thus, there is currently a fairly broad picture of the modifications that different predators produce on the bones of small mammals (e.g., Andrews, 1990; Fernández-Jalvo and Andrews, 1992; Laudet and Selva, 2005; Lloveras et al., 2008; Esteban-Nadal et al., 2010; Denys, 2011; Souttou et al., 2012; Fernández-Jalvo et al., 2016; Campmas et al., 2018; Denys et al., 2018; Royer et al., 2019). Samples of small fish, amphibians, reptiles and birds were only occasionally evaluated; in those cases, an alternative methodology was used to better fit the morphology of the bones of these microvertebrates (Bochenski et al., 1993, 2009; Bochenski and Tomek, 1994; Pinto Llona and Andrews, 1999; Castillo et al., 2001; Bochenski and Tornberg, 2003; Bochenski, 2005; Broughton et al., 2006; Bailon, 2011; Russ and Jones, 2011; Guillaud et al., 2017).

Andrews (1990) and Fernández-Jalvo and Andrews (1992) suggested that the most relevant criterion to distinguish the effects produced during predation on small mammal bones is the evaluation of the modifications of their surface caused by the digestive acids of the predator. In this sense, five categories of modifications were established for evaluating changes in bones surface and frequencies of affected skeletal elements in each type of predator. In particular, this evaluation considers marks of digestive corrosion on teeth, proximal femora and distal humeri, the degree 
of breakage in cranial (four categories of skull breakage and four categories for mandibles were considered) and postcranial remains (i.e., proximal, shaft and distal segments), and the relative abundance of skeletal parts. A classification of these categories based on the observed modifications in a gradient of increasing alteration is herein proposed: light, intermediate, moderate, heavy and extreme. Broadly, the first categories, with a level of light to moderate alteration, include nocturnal bird raptors while moderate to heavy levels of alteration were associated with diurnal bird raptors, and, finally, the highest degree of modification was correlated with carnivore mammals.

In general, all of the aforementioned attributes were evaluated. Yet, recently, Fernández-Jalvo et al. (2016) proposed an evaluation of only corrosion by digestive acids on teeth, according to each taxon (rodents and soricomorphs) present in each accumulation, for different places of North America, Europe and Africa. The authors proposed a complementary change in the methodology of observation of molariforms by looking for characteristics typical of corrosion by digestion. They highlighted the importance of the study of the occlusal surface of these teeth to add it to the classic observation of lateral views, especially for arvicoline molars. These complementary methodologies have been applied in most actualistic papers of the South American fauna, which will be mentioned below (Fernández-Jalvo et al., 2016).

For South America, several papers related to micromammal assemblage evaluations have dealt with the categorization of predators according to the modifications that they produce on prey bones, using their own methodologies for each case (Pardiñas, 1996-1998, 1999a; Saavedra and Simonetti, 1998; Mondini, 2000, 2001, 2012, 2017; Cruz, 2008; Mondini and Muñoz, 2008). However, in the last 20 years, the number of actualistic papers has increased, especially those concerning central Argentina (see Fernández and Montalvo, 2017), in which the methodology proposed by Andrews (1990) and Fernández-Jalvo and Andrews (1992) is employed in the evaluation of the accumulated digested small mammal bones (mainly rodents). The evaluations carried out on samples produced by Strigiformes birds [Tyto alba (Scopoli, 1769), Athene cunicularia (Molina, 1782), Bubo virginianus magellanicus (Gmelin, 1788), B. virginianus nacurutu (Vieillot, 1817), Pseudoscops clamator (Vieillot, 1808), Asio flammeus (Pontoppidan, 1763), Strix chacoensis Cherrie and Reichenberger, 1921], Accipitriformes and Falconiformes birds [Circus buffoni (Gmelin, 1788), Geranoaetus melanoleucus (Vieillot, 1819), Geranoaetus polyosoma (Quoy and Gaimard, 1824), Elanus leucurus (Vieillot, 1818), Caracara plancus (Miller, 1777), Milvago chimango (Vieillot, 1816)] and mammals [Didelphis albiventris Lund, 1840, Lycalopex griseus (Gray, 1837), Puma concolor (Linnaeus, 1771), P. yagouaroundi (Geoffroy Saint-Hilaire, 1803), Conepatus chinga (Molina, 1782), Leopardus geoffroyi (d'Orbigny and Gervais, 1844), Lontra longicaudis (Olfers, 1818)], enabled the allocation of these predators within the different modification categories that had been previously proposed (Gómez, 2005, 2007; Gómez and Kaufmann, 2007; Montalvo et al., 2007, 2008b, 2012a, 2014, 2015, 2016b; Montalvo and Tallade, 2009; Fernández et al., 2009a; Carrera and Fernández, 2010; Fernández, 2012; Rudzik et al., 2015; Quintana, 2015; López et al., 2017a,b, 2018).

The studying of South American small mammal prey and their evaluation include the Didelphidae marsupials and the rodents Cricetidae Sigmodontinae, Ctenomyidae, Abrocomidae and Caviidae Caviinae. Noteworthy, although the dental features of the above mentioned taxa differ from those of the North American prey, the methodology of evaluation applied was the same as in those cases. However, because these differences, as well as the biases in the interpretation that could be generated, were known, similarities and differences in the modifications of the different prey were recently evaluated (Fernández et al., 2017). Thus, the digestive effects on the aforementioned South American taxa were analyzed and compared with those that were described for the North American, African and European fauna. The results showed a sequence of modification events according to the taxa recorded in a sample (Fernández et al., 2017).

In the previously mentioned papers, the use of the same methodology to evaluate the samples is suggested; even so, it is clear that problems arise with the way in which some of the attributes of interest are quantified and interpreted. For example, in many papers, only the MNE (minimum number of skeletal elements) is reported; yet, nor the $\mathrm{n}$ (total number of recovered remains, including fragments 
and the anatomically indeterminable splinters), neither the NISP (number of specimens identified per taxon), are acknowledged. These indices are of great interest since the comparison between the values enriches the knowledge on the proportion of identifiable remains in the sample. It is noteworthy that, in the case of predators that cause strong and extreme changes, these comparative values may indicate a greater or lesser degree of destruction of the bones. They also become important when linked with the body mass of the prey, since it is expected that the greater the estimated body mass, the greater the degree of bone breakage and, therefore, a larger number of non-identifiable remains would be expected.

In most papers, all the taxa recorded in the samples are mentioned but only those of mammals and, particularly, rodents, are highlighted and adjusted taxonomically whereas the rest are only classified up to the Order or Class level. A few studies evaluate other taxa besides rodents; that is, mainly amphibians, reptiles and birds (Fernández et al., 2009b; Montalvo and Tejerina, 2009; Montalvo et al., 2011; Fernández, 2012; Quintana, 2015; Denys et al., 2018; Royer et al., 2019). As mentioned above, it is noteworthy that these groups of vertebrates are treated according to their own methodology of evaluation (Bochenski et al., 1993, 2009; Bochenski and Tomek, 1994; Pinto Llona and Andrews, 1999; Castillo et al., 2001; Bochenski and Tornberg, 2003; Bochenski, 2005), which should be put to test with more samples of South American fauna. Recently, Denys et al. (2018) valued the presence, in samples of North African predators, not only of rodents, but also of other taxa such as birds, amphibians and insects. These authors suggested that the use of this type of evaluation, which includes all the taxa involved in a fossil assemblage, can improve palaeoecological interpretations.

The evaluation of the modifications produced by a predator on small vertebrates in South America, used as modern analogs, facilitate the resolution of problems and interpretations of zooarchaeological and/or palaeontological assemblages. 37\% of the studies analyzed herein are concerned with the evaluation of the modifications produced by the predator in order to link these results with the data of archaeological or fossil sites. The remaining $63 \%$ are exclusively concerned with the modifications produced by the predator as a way of approaching the evaluation of their behavior. The latter also constitute an important database to evaluate new sites with small vertebrate fossils of apparent biological origin.

Digestive corrosion is the greatest evidence of predation (Andrews, 1990; Fernández-Jalvo et al., 2016; Fernández et al., 2017). This evidence was evaluated on distal humeri, proximal femora, incisors and molars (Andrews, 1990; Fernández-Jalvo and Andrews, 1992), and such evaluation was based both on the degree of modification and the proportion of the bone affected by this corrosion. This methodology was followed with most samples of South American predators. Fernández-Jalvo et al. (2016) and Fernández et al. (2017) recently suggested that modifications on incisors and molars were enough to give pertinent information; these updated criteria were used in the evaluation of South American samples of G. melanoleucus, G. polyosoma and S. chacoensis (López et al., 2017a, 2018).

\section{South American predators}

At present, numerous birds of prey and predatory mammals inhabit South America (Thiollay, 1994; White et al., 1994; Bruce, 1999; Marks et al., 1999; Wilson and Reeder, 2005). Taphonomic evaluations include a broad range of taxa: seven species of nocturnal raptors (Strigiformes), six diurnal raptors (four Accipitriformes and two Falconiformes) and seven mammalian predators (one Canidae, three Felidae, one Mephitidae, one Mustelidae and one marsupial species). Their natural histories, including their type of nest, their perch and burrows, their habits, their diet, their habitat and their geographic distribution, are described in Table 1.

Except for T. alba, which has a worldwide distribution, and $A$. flammeus, whose distribution includes part of Europe and Asia, the rest of the predators are part of the typical American fauna and, some, are even restricted to South America (Figs. 1-3). Only S. chacoensis has a small distribution area (Fig. 1). A single species of the genus Bubo Dumeril, 1805 inhabits South America: Bubo virginianus (Gmelin, 1788). Nonetheless, in line with the original taphonomic paper (cf. Montalvo et al., 2016b), we have herein considered the subspecific forms of $B$. v. magellanicus and $B$. v. nacurutu. The first one is marked by an Andean Patagonian distribution, from central Peru to southern Chile and Argentina 
TABLE 1 - Summary of the main characteristics of the South American studied predators. Main sources: Redford and Eisenberg (1992), Thiollay (1994), White et al. (1994), Bruce (1999), Marks et al. (1999), and Wilson and Reeder (2005)

\begin{tabular}{|c|c|c|c|c|}
\hline $\begin{array}{l}\text { Species and their common } \\
\text { names }\end{array}$ & $\begin{array}{l}\text { Nesting site, perches, } \\
\text { burrows }\end{array}$ & Habits & Diet & Habitat \\
\hline \multicolumn{5}{|l|}{ Aves Strigiformes } \\
\hline $\begin{array}{l}\text { Tyto alba } \\
\text { (Barn Owl) }\end{array}$ & $\begin{array}{l}\text { Caves, rock shelters, } \\
\text { human buildings }\end{array}$ & $\begin{array}{l}\text { Nocturnal, crepuscular, } \\
\text { solitary }\end{array}$ & $\begin{array}{l}\text { Microvertebrates (mostly sigmodontine } \\
\text { rodents), occasionally insects }\end{array}$ & Environmental diversity \\
\hline $\begin{array}{l}\text { Athene cunicularia } \\
\text { (Burrowing Owl) }\end{array}$ & $\begin{array}{l}\text { Small holes in the } \\
\text { ground }\end{array}$ & $\begin{array}{l}\text { Diurnal, nocturnal, } \\
\text { gregarious }\end{array}$ & $\begin{array}{l}\text { Microvertebrates (mainly sigmodontine } \\
\text { rodents), occasionally insects }\end{array}$ & Environmental diversity \\
\hline $\begin{array}{l}\text { Bubo virginianus } \\
\text { (Great Horned Owl) }\end{array}$ & $\begin{array}{l}\text { Cliffs, rock shelters, } \\
\text { trees, bushes }\end{array}$ & $\begin{array}{l}\text { Nocturnal, crepuscular, } \\
\text { solitary }\end{array}$ & $\begin{array}{l}\text { Microvertebrates (mostly sigmodontine } \\
\text { rodents), occasionally insects }\end{array}$ & Environmental diversity \\
\hline $\begin{array}{l}\text { Asio flammeus } \\
\text { (Short-eared Owl) }\end{array}$ & Ground & $\begin{array}{l}\text { Diurnal, crepuscular, } \\
\text { nocturnal, solitary }\end{array}$ & $\begin{array}{l}\text { Microvertebrates (mainly sigmodontine } \\
\text { rodents), occasionally insects }\end{array}$ & Open environments \\
\hline $\begin{array}{l}\text { Pseudoscops clamator } \\
\text { (Striped Owl) }\end{array}$ & Ground, trees & $\begin{array}{l}\text { Nocturnal, crepuscular, } \\
\text { solitary }\end{array}$ & $\begin{array}{l}\text { Microvertebrates (mainly } \\
\text { rodents), occasionally insects }\end{array}$ & $\begin{array}{l}\text { Environmental diversity } \\
\text { in lowlands }\end{array}$ \\
\hline $\begin{array}{l}\text { Strix chacoensis } \\
\text { (Chaco Owl) }\end{array}$ & Trees & Nocturnal, solitary & $\begin{array}{l}\text { Microvertebrates (mainly sigmodontine } \\
\text { rodents), occasionally insects }\end{array}$ & Environments of Chaco \\
\hline \multicolumn{5}{|l|}{ Accipitriformes } \\
\hline $\begin{array}{l}\text { Geranoaetus melanoleucus } \\
\text { (Black-chested Buzzard-eagle) }\end{array}$ & $\begin{array}{l}\text { Cliffs, rock shelters, } \\
\text { trees }\end{array}$ & Diurnal, solitary & $\begin{array}{l}\text { Micromammals (mostly rodents), } \\
\text { secondarily birds }\end{array}$ & Environmental diversity \\
\hline $\begin{array}{l}\text { Geranoaetus polyosoma } \\
\text { (Variable Hawk) }\end{array}$ & $\begin{array}{l}\text { Cliffs, rock shelters, } \\
\text { trees, bushes }\end{array}$ & Diurnal, solitary & $\begin{array}{l}\text { Micromammals (mainly sigmodontine } \\
\text { rodents), occasionally insects }\end{array}$ & $\begin{array}{l}\text { Environments of Andes, } \\
\text { Chaco, Pampa, Patagonia }\end{array}$ \\
\hline $\begin{array}{l}\text { Elanus leucurus } \\
\text { (White-tailed Kite) }\end{array}$ & Trees, fence posts & $\begin{array}{l}\text { Diurnal, occasionally } \\
\text { gregarious }\end{array}$ & Microvertebrates, mostly rodents & $\begin{array}{l}\text { Environmental diversity } \\
\text { in lowlands }\end{array}$ \\
\hline $\begin{array}{l}\text { Circus buffoni } \\
\text { (Long-winged Harrier) }\end{array}$ & $\begin{array}{l}\text { High and humid } \\
\text { grasslands }\end{array}$ & Diurnal, solitary & $\begin{array}{l}\text { Microvertebrates, mainly rodents } \\
\text { and birds }\end{array}$ & $\begin{array}{l}\text { Environmental diversity } \\
\text { in open and lowlands }\end{array}$ \\
\hline \multicolumn{5}{|l|}{ Falconiformes } \\
\hline $\begin{array}{l}\text { Caracara plancus } \\
\text { (Southern Crested Caracara) }\end{array}$ & Trees & Diurnal, gregarious & $\begin{array}{l}\text { Hunts microvertebrates and consumes } \\
\text { dead animals of different sizes }\end{array}$ & Environmental diversity \\
\hline $\begin{array}{l}\text { Milvago chimango } \\
\text { (Chimango Caracara) }\end{array}$ & $\begin{array}{l}\text { Cliffs, rock shelters, } \\
\text { trees }\end{array}$ & Diurnal, gregarious & $\begin{array}{l}\text { Hunts microvertebrates and consumes } \\
\text { dead animals of different sizes }\end{array}$ & Environmental diversity \\
\hline \multicolumn{5}{|l|}{ Mammalia } \\
\hline \multicolumn{4}{|l|}{ Carnivora } & \\
\hline $\begin{array}{l}\text { Lycalopex griseus } \\
\text { (Argentine Gray Fox) }\end{array}$ & $\begin{array}{l}\text { Cracks in rocks, } \\
\text { trees, bushes }\end{array}$ & $\begin{array}{l}\text { Nocturnal, occasionally } \\
\text { gregarious }\end{array}$ & $\begin{array}{l}\text { Microvertebrates (mostly rodents), } \\
\text { mesovertebrates, arthropods, fruits }\end{array}$ & $\begin{array}{l}\text { Environments of Chaco, } \\
\text { Pampa, Patagonia }\end{array}$ \\
\hline \multicolumn{5}{|l|}{ Felidae } \\
\hline $\begin{array}{l}\text { Puma concolor } \\
\text { (Puma) }\end{array}$ & $\begin{array}{l}\text { Caves, rock shelters, } \\
\text { trees }\end{array}$ & $\begin{array}{l}\text { Nocturnal, crepuscular, } \\
\text { solitary }\end{array}$ & $\begin{array}{l}\text { Vertebrates of different sizes, } \\
\text { mainly large and mesomammals }\end{array}$ & Environmental diversity \\
\hline $\begin{array}{l}\text { Puma yagouaroundi } \\
\text { (Jaguarundi) }\end{array}$ & Trees, bushes & Diurnal, solitary & $\begin{array}{l}\text { Microvertebrates, occasionally } \\
\text { mesovertebrates }\end{array}$ & Environmental diversity \\
\hline $\begin{array}{l}\text { Leopardus geoffroyi } \\
\text { (Geoffroy's Cat) }\end{array}$ & $\begin{array}{l}\text { Caves, rock shelters, } \\
\text { trees }\end{array}$ & Nocturnal, solitary & $\begin{array}{l}\text { Microvertebrates (mainly rodents } \\
\text { and lagomorphs), occasionally insects }\end{array}$ & Environmental diversity \\
\hline \multicolumn{5}{|l|}{ Mustelidae } \\
\hline $\begin{array}{l}\text { Lontra longicaudis } \\
\text { (Neotropical Otter) }\end{array}$ & Riparian tree roots & $\begin{array}{l}\text { Diurnal, semi-aquatic, } \\
\text { occasionally gregarious }\end{array}$ & $\begin{array}{l}\text { Fish and crustaceans, in addition } \\
\text { insects, molluscs, microvertebrates }\end{array}$ & $\begin{array}{l}\text { Fluvial, tropical, } \\
\text { temperate environments }\end{array}$ \\
\hline \multicolumn{5}{|l|}{ Mephitidae } \\
\hline $\begin{array}{l}\text { Conepatus chinga } \\
\text { (Molina's Hog-nosed Skunk) }\end{array}$ & $\begin{array}{l}\text { Small holes in the } \\
\text { ground }\end{array}$ & Nocturnal, solitary & $\begin{array}{l}\text { Diversity of arthropods, } \\
\text { microvertebrates and plants }\end{array}$ & Environmental diversity \\
\hline \multicolumn{5}{|l|}{ Didelphimorphia } \\
\hline $\begin{array}{l}\text { Didelphis albiventris } \\
\text { (White-eared Opossum) }\end{array}$ & Trees & Nocturnal, solitary & $\begin{array}{l}\text { Diversity of arthropods, } \\
\text { microvertebrates and plants }\end{array}$ & $\begin{array}{l}\text { Environmental diversity } \\
\text { in lowlands }\end{array}$ \\
\hline
\end{tabular}


while the second, by a distribution extending at the east of the Andean Cordillera, from central Brazil to central Buenos Aires province in Argentina (Marks et al., 1999).
Actualistic papers deal exclusively with samples collected from different regions of Argentina although mainly from the central area (Fig. 4). The number of predators involved in

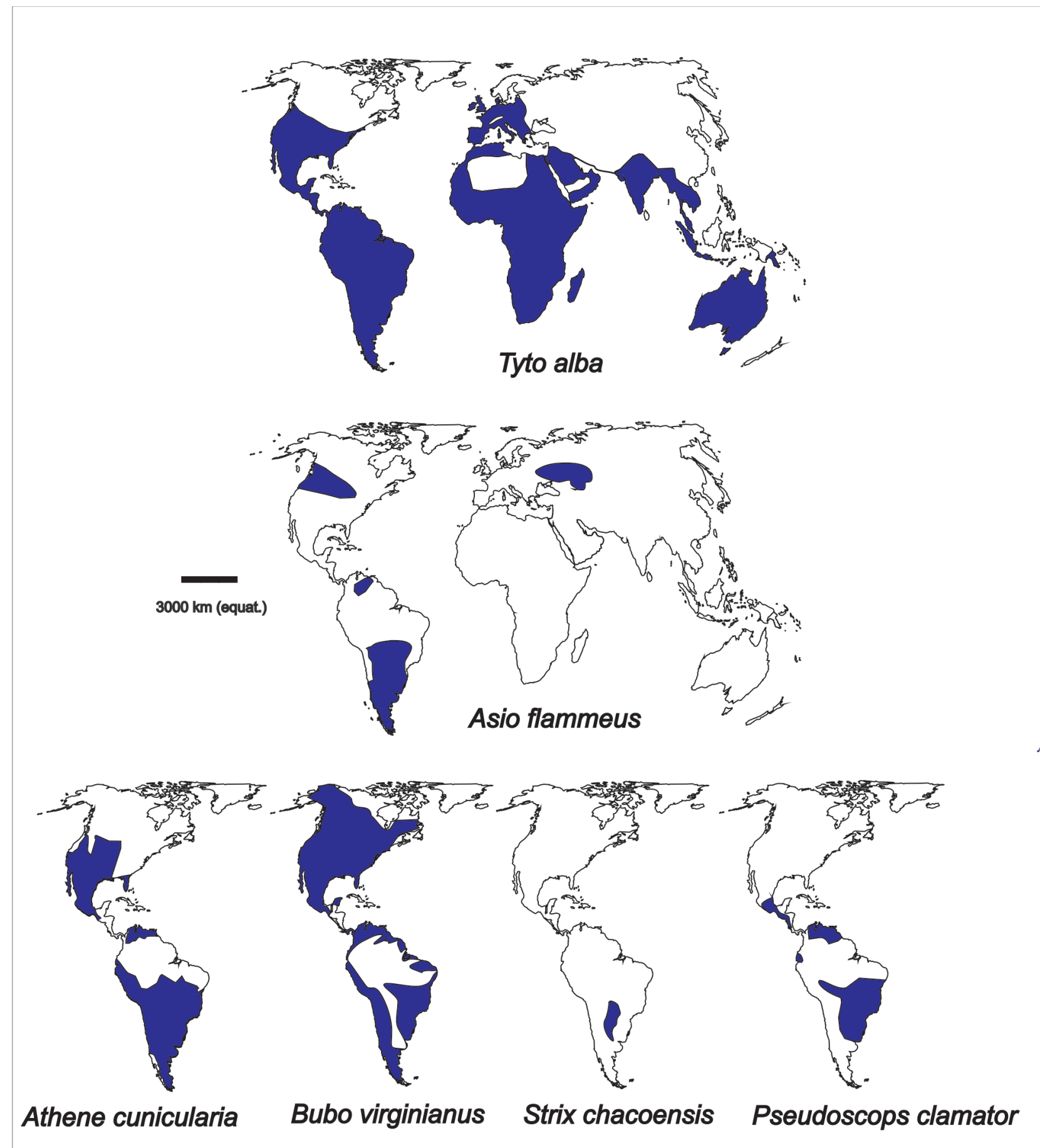

Figure 1. Distribution of the analyzed nocturnal raptors (resident area). 
these studies must be increased; in addition, it is necessary to search for new material produced by the same predators but from other regions of Argentina and America. This will probably result in variations in the data regarding the modifications on the bones of their prey. Additionally, the extension of the geographical area to be studied will increase the possibility of evaluating a greater diversity of prey taxa. This feature is important when these results are used as analogous in the evaluation of fossil and zooarchaeological samples.
Most of the studied samples of these actualistic researches belong to Strigiformes because they correspond to organisms that feed on microvertebrates, mainly sigmodontine rodents. Also, some species of this order, such as T. alba and B. v. magellanicus, can nest and perch in caves, rock shelters or cliffs (Tab. 1). Some diurnal species of Accipitriformes, such as G. melanoleucus and G. polyosoma, could present similar trophic and nesting habits. This selection is coherent with the most frequent taphonomic expectations in archaeological and palaeontological sites.

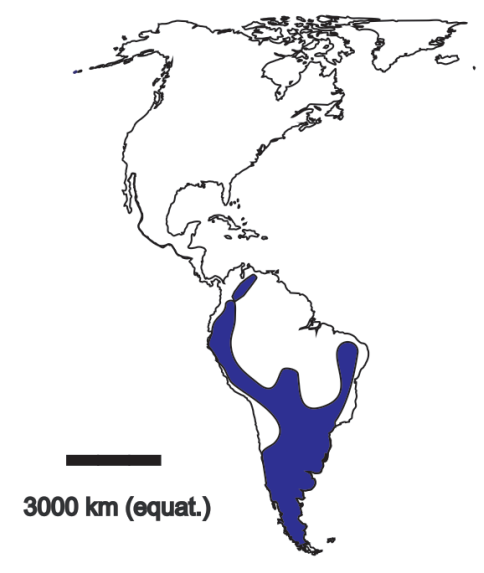

Geranoaetus melanoleucus

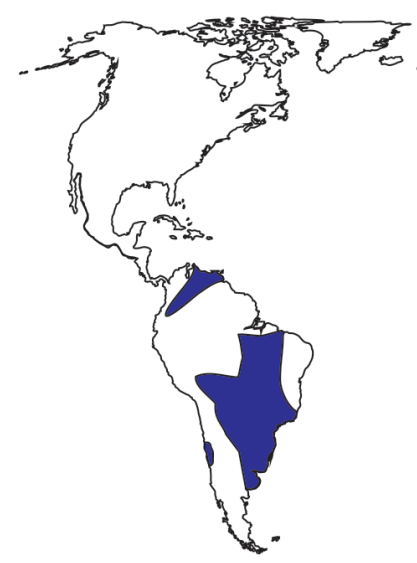

Circus buffoni

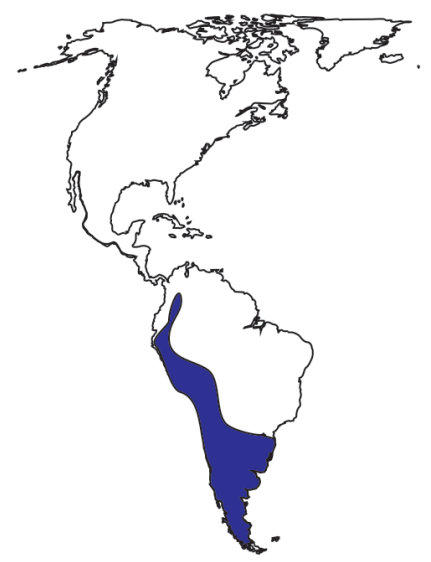

Geranoaetus polyosoma

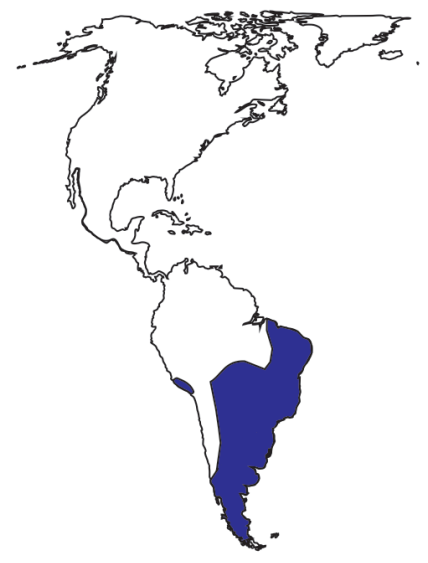

Caracara plancus

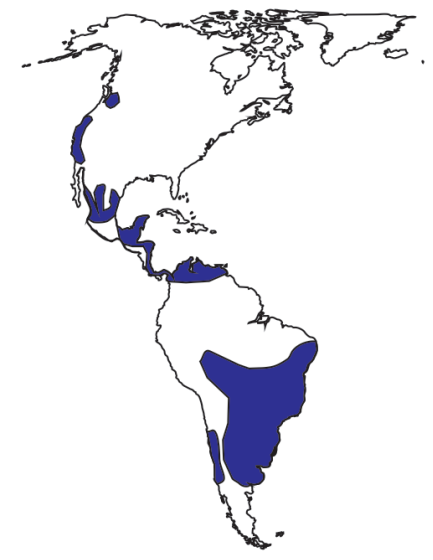

Elanus leucurus

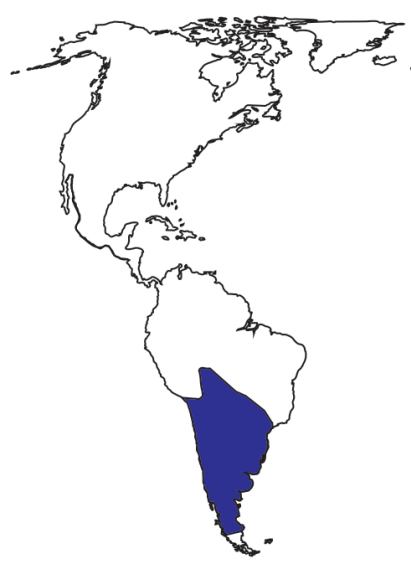

Milvago chimango

Figure 2. Distribution of the analyzed diurnal raptors (resident area). 

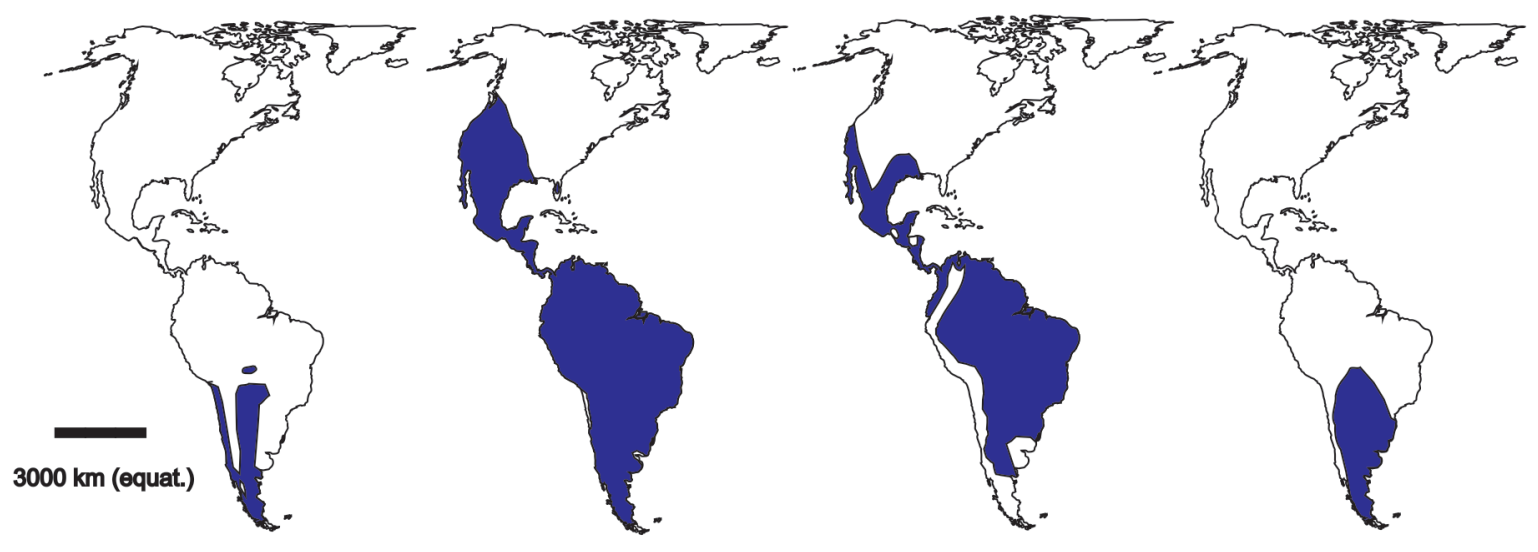

\section{Lycalopex griseus Puma concolor Puma yagouaroundi Leopardus geoffroyi}

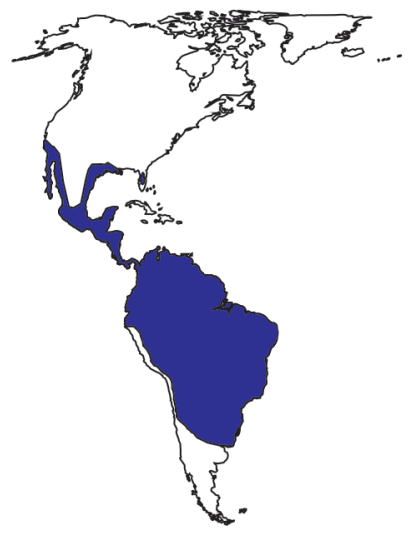

Lontra longicaudis

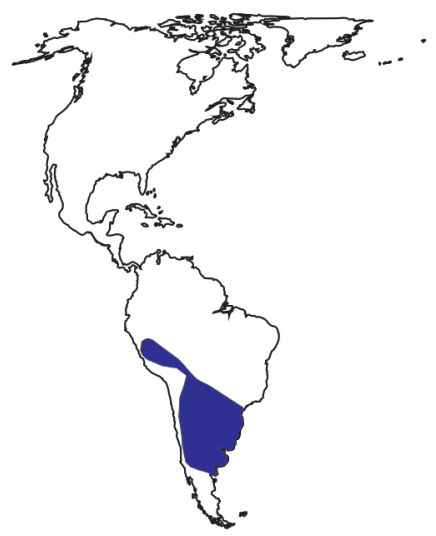

Conepatus chinga

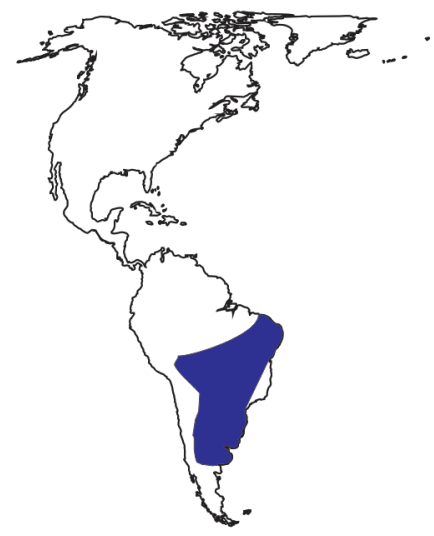

Didelphis albiventris

Figure 3. Distribution of the analyzed carnivore mammals.

\section{MATERIALS AND METHODS}

Several small mammal samples with taphonomic information from different places of central and south Argentina, and which were produced by hunting and digestion of 20 predator species (see section South American predators), had been previously evaluated by different authors (Supp. inf. 1) using the standard methodology of Andrews (1990) and Fernández-Jalvo and Andrews (1992) explained above (see section Current status of the small mammals taphonomy). In three predator samples (G. melanoleucus, G. polyosoma and S. chacoensis), the methodology of digestive corrosion on teeth proposed by Fernández et al. (2017) was added.

Here, a dataset of all small mammal samples with actualistic taphonomy information taken from the literature (Suppl. inf. 1) was collected with the following taphonomic attributes: 1) Diet composition: taking into account broad category items (e.g., rodents, marsupials); 2) Relative abundance of skeletal elements: considering the representativity of each element in the sample (MNEi) as a function of the expected number of that specific skeletal element in the 
individual (Ei) and MNI (minimal number of individuals), after: MNEi / (Ei x MNI) x 100; 3) Two indices of postcranial/cranial elements: $\mathrm{pc}=[($ femur + tibia + humerus + radius + ulna $) \mathrm{x}$ 16/(mandible + maxilla + molars) x 10] x 100, and [(humerus + femur)/(mandible + maxilla)] x 100;4) Index of distal and proximal limb elements: [(tibia + radius)/(femur + humerus)] $x$ 100; 5) Two indices of isolated teeth: [(maxillary alveoli + mandibular alveoli)/(molars)] x 100; and [(premaxillary alveoli + mandibular alveoli)/(incisors)] x 100; 6) Corrosion marks: produced by digestive acids and observed on the surfaces of teeth (i.e., incisors and molars) and postcranial remains (i.e., proximal epiphysis of femur and distal epiphysis of humerus). In order to homogenize all the samples of the different predators, the total proportion of remains with evidence of digestive corrosion was evaluated; 7) Breakage: skulls, mandibles, teeth and postcranial elements (femur, humerus, tibia, ulna), counting both whole and broken remains.
Considering the study and comparisons of these small mammal samples, and the proposed categories evaluated for each predator (Supp. inf. 1), the categories of modification for the South American predators were reviewed.

A correspondence analysis was conducted in order to explore the ordination of samples in a multivariate space. This evaluation was made on a data matrix composed of the main taphonomic attributes that were taken into account: the average of relative abundances, the proportions of the categories of digestion, the proportions of breakage, the index distal/proximal elements and the two indices of postcrania/crania. In addition, a ternary diagram was based on the most relevant taphonomic attributes: the average of relative abundances, the proportions of the categories of digestion and the proportions of breakage. Statistical analyses were made using the program PAST (PAleontological Statistics; Hammer et al., 2001), version 3.12.

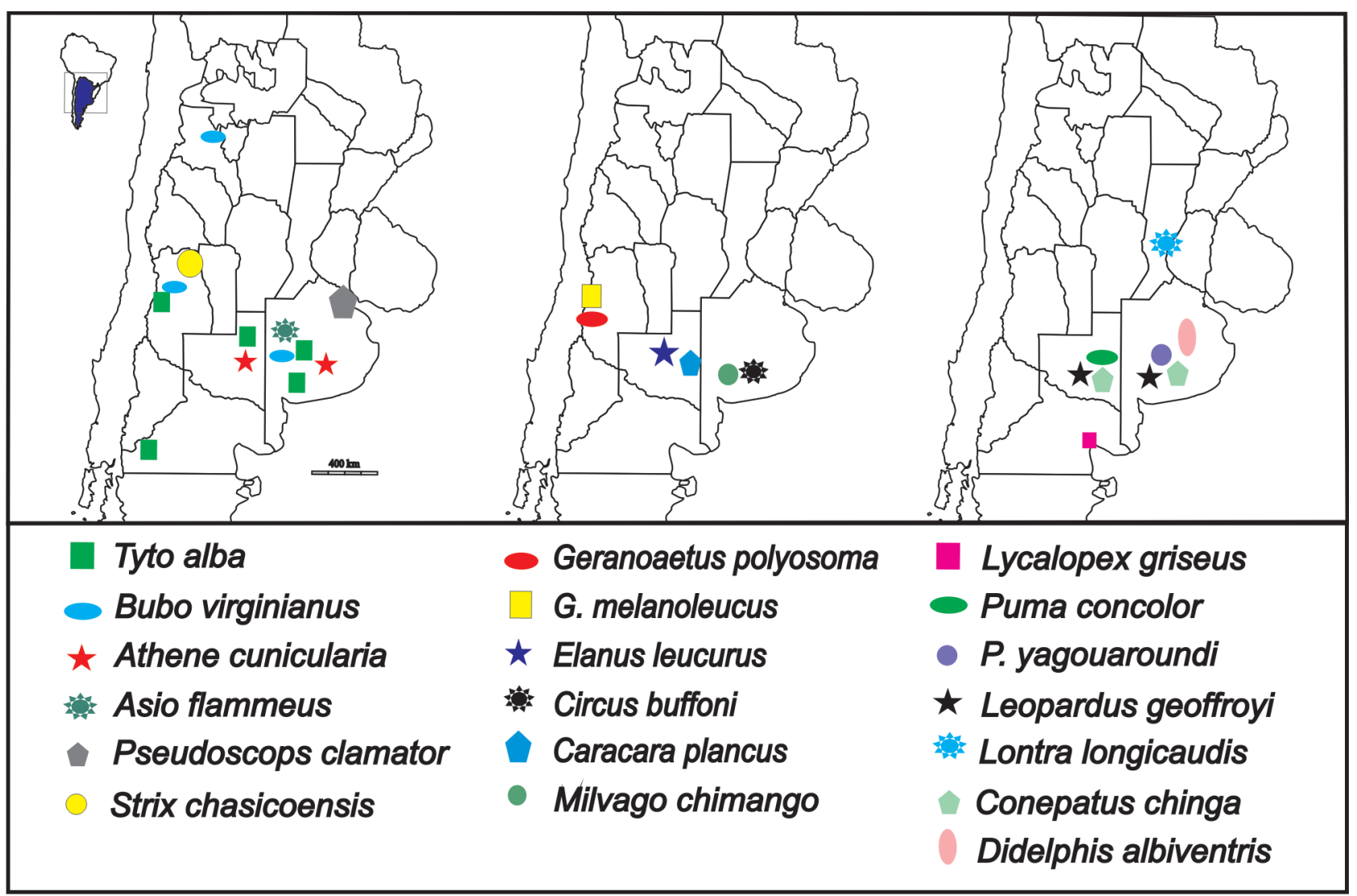

Figure 4. Geographical distribution of samples from different predators. 
(1)
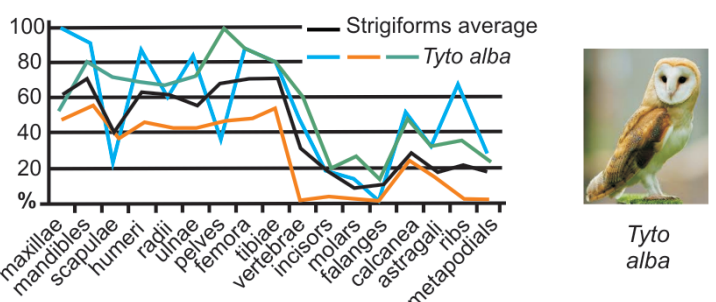

(2)
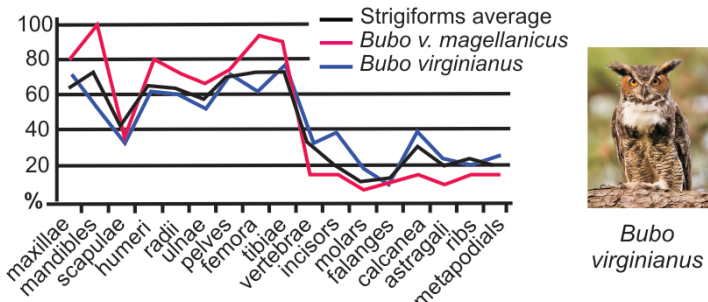

(3)

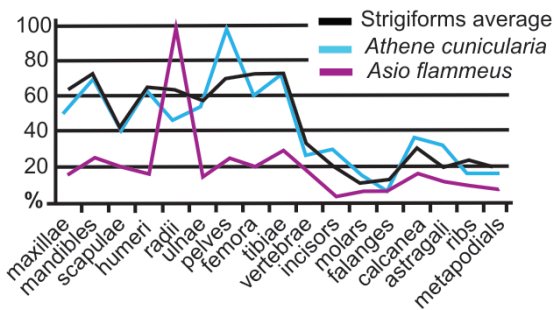

(4)

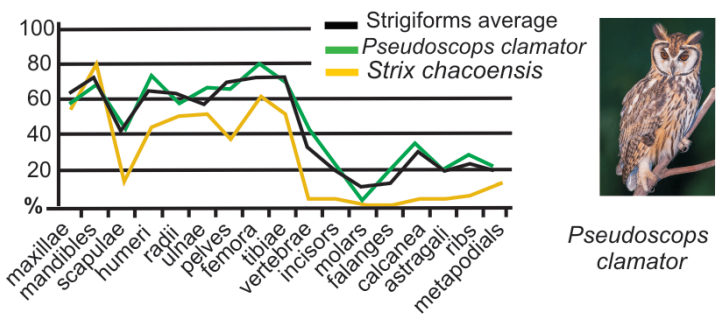

Figure 5. Relative abundance of different South American Strigiformes compared with their total average. 1, Tyto alba (Iglesias, 2009; Fernández et al., 2009a; Gómez, 2007); 2, Bubo v. magellanicus (Montalvo et al., 2016b), Bubo magellanicus (Gómez, 2005); 3, Athene cunicularia average samples (Gómez, 2007; Montalvo and Tejerina, 2009), Asio flammeus (Gómez, 2007); 4, Pseudoscops clamator average samples (Rudzik et al., 2015; Carrera and Fernández, 2009), and Strix chacoensis (López et al., 2018).

\section{RESULTS AND DISCUSSION Nocturnal raptors}

Relative abundance and degree of breakage. The average of relative abundance of elements produced by South American nocturnal raptors was of $42.95 \%$ (Suppl. inf. 2).

Figure 5 shows the comparison between the curves of relative abundance of strigiform species and their total average. The average curve is characterized by a higher abundance of maxillae, mandibles, humeri and femora, and the low representativity of isolated teeth, vertebrae, ribs and autopodials. Some raptors, such as Bubo and P. clamator (Gómez, 2007; Rudzik et al., 2015; Montalvo et al., 2016b), follow this tendency. However, $T$. alba displays great variability, and the other species showed some differences as well (Gómez, 2007; Iglesias, 2009; Fernández et al., 2009a). For example, A. cunicularia yields greater abundance of pelves (Gómez, 2007; Montalvo and Tejerina, 2009) while A. flammeus shows higher values of radii and lesser values in the other elements (Gómez, 2007), and S. chacoensis produces a pattern similar to that of the average strigiforms but with lower values (López et al., 2018).

Among Strigiformes (Suppl. inf. 1), the samples produced by T. alba included some complete skulls; i.e., those skulls preserving intact maxillae and frontal bones, and at least half of cranial vault (Andrews, 1990). Breakage values in these samples varied between $19 \%$ and $25 \%$. Iglesias (2009) obtained a higher number of broken skulls in her sample ( $78 \%$ ), but the result included more than $22 \%$ of complete skulls. In our sample of $B$. v. magellanicus, most of the skull fragments corresponded to maxilla without zygomatic arches though 49 skulls were more complete (Montalvo et al., 2016b); however, in those studied by Gómez (2005, 2007), all skulls showed breakages. In the sample of $A$. cunicularia, there are no complete skulls (Montalvo and Tejerina, 2009) whereas, in those of $P$. clamator and $S$. chacoensis, most skulls are complete (Carrera and Fernández, 2010; Rudzik et al., 2015; López et al., 2018). Among the mandibles of this predator group, the situation is different because the values of broken mandibles ranged from $17.02 \%$ to $80 \%$, with a mean of $56.65 \%$, and the samples of $S$. chacoensis and $T$. alba were marked by yielding the highest number of complete mandibles. Andrews (1990) stated that mandibles are commonly preserved in the assemblage produced by different predators, and that the smallest the size of the prey, the better preservation of the mandibles will be. Strigiformes samples have the largest number of whole mandibles (Andrews, 1990); thus, the values obtained thereby are consistent in terms of average, even when considering the aforementioned variations.

Among the postcranial elements, the samples from Strigiformes had a very low percentage of broken skeletal elements (Fig. 6.1).

Degree of digestion. In the samples of T. alba, $82.7 \%$ of the 
skeletal remains showed no digestive corrosion. $A$. flammeus (70.4\%), S. chacoensis (67.9\%), B. v. nacurutu (61.8\%), B. v. magellanicus $(26.9 \%)$ and $P$. clamator $(25 \%)$ follow in descending order. The samples of $A$. cunicularia showed digestive corrosion in all $(100 \%)$ remains. As seen in Figure 7.1 , the predominant category in the Strigiformes samples is light digestion. This degree of modification affects all the remains of the samples of A. flammeus (Gómez, 2007). Moderate modifications were recorded in all the samples of Strigiformes in different proportions (0-29.4\%), with $A$. cunicularia (Gómez, 2007; Montalvo and Tejerina, 2009) and B. v. magellanicus (Montalvo et al., 2016b) yielding the maximum values. Extreme modifications are recorded only in samples of A. cunicularia (Gómez, 2007; Montalvo and Tejerina, 2009) and Bubo (Gómez, 2005; Montalvo et al., 2016b).
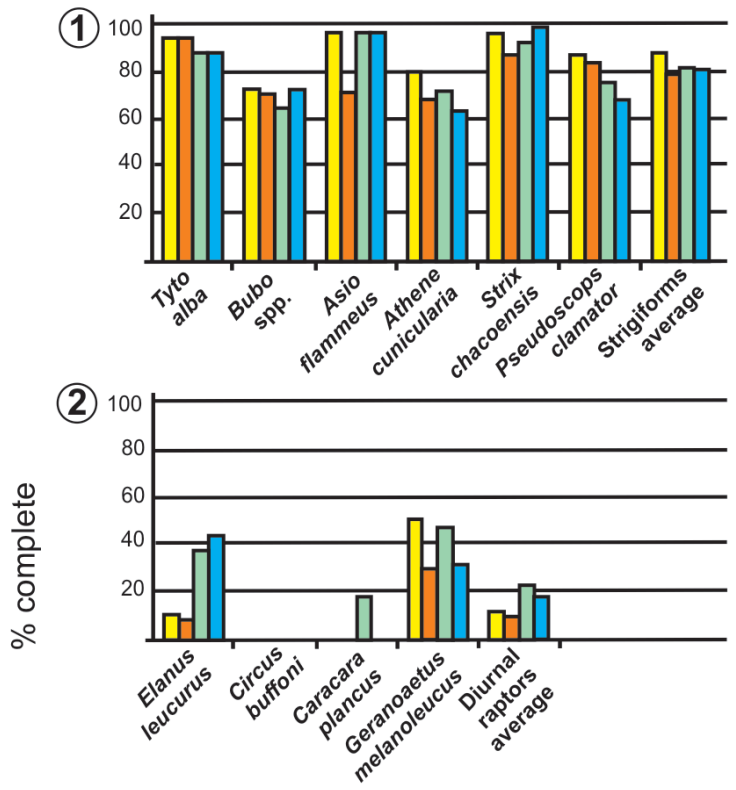

(3) 1

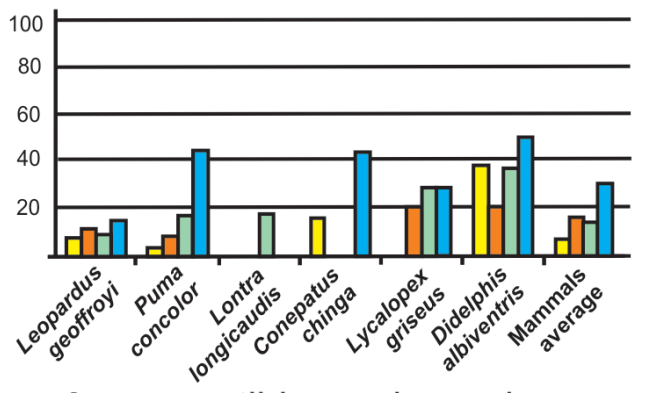

\section{$\square$ femora $\square$ tibiae $\square$ humeri $\square$ ulnae}

Figure 6. Breakage degree. Percentage evaluated for each predator on femora, tibiae, humeri and ulnae. 1, Nocturnal raptors; 2, diurnal raptors; 3 , carnivore mammals.

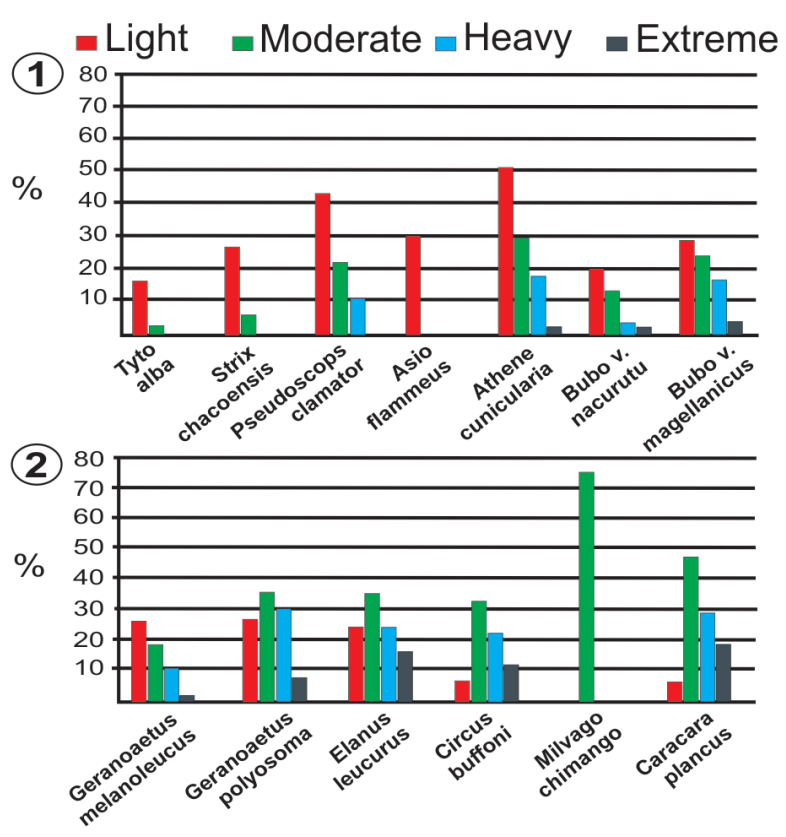

(3)

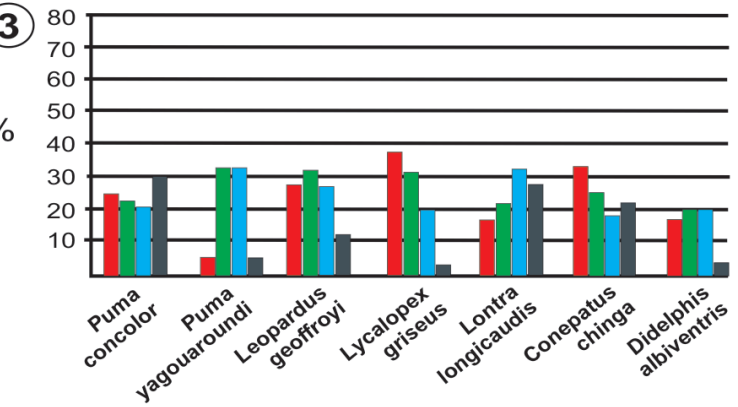

Figure 7. Digestion degree. Percentage evaluated for each predator on femora, humeri and teeth. 1, Nocturnal raptors; 2, diurnal raptors; 3, carnivore mammals.

\section{Diurnal raptors}

Relative abundance and degree of breakage. The average of relative abundance of South American diurnal raptors was 26.05\% (Suppl. inf. 2).

Figure 8 displays the comparison of the curves of relative abundance of the falconiform and accipitriform species and their average. The curve of average of species is described by higher values of maxillae, mandibles and isolated incisors, and lower values of scapulae, radii, vertebrae, ribs and autopodials. Although with some differences, all the species display a similar pattern. For example, the accipitrid E. leucurus yields greater abundance of maxillae and femora, and lesser abundance of autopodials with respect to the average of diurnal raptors (Montalvo et al., 2014). The ac- 
cipitrid C. buffoni produces higher values of maxillae and isolated incisors, and lower values of almost all other elements (Gómez, 2007). The accipitrid G. polyosoma generates more humeri and fewer pelves (López et al., 2017a). The falconid C. plancus yields more femora and autopodials, and fewer maxillae (Montalvo and Tallade, 2009).

Among diurnal raptors, the degree of skull and mandible breakage was higher than in Strigiformes. The sample of $C$. plancus yielded all such skeletal elements broken (Montalvo and Tallade, 2009) whereas, in E. leucurus, no whole skulls were recovered but $5.72 \%$ of the mandibles were complete

(1)
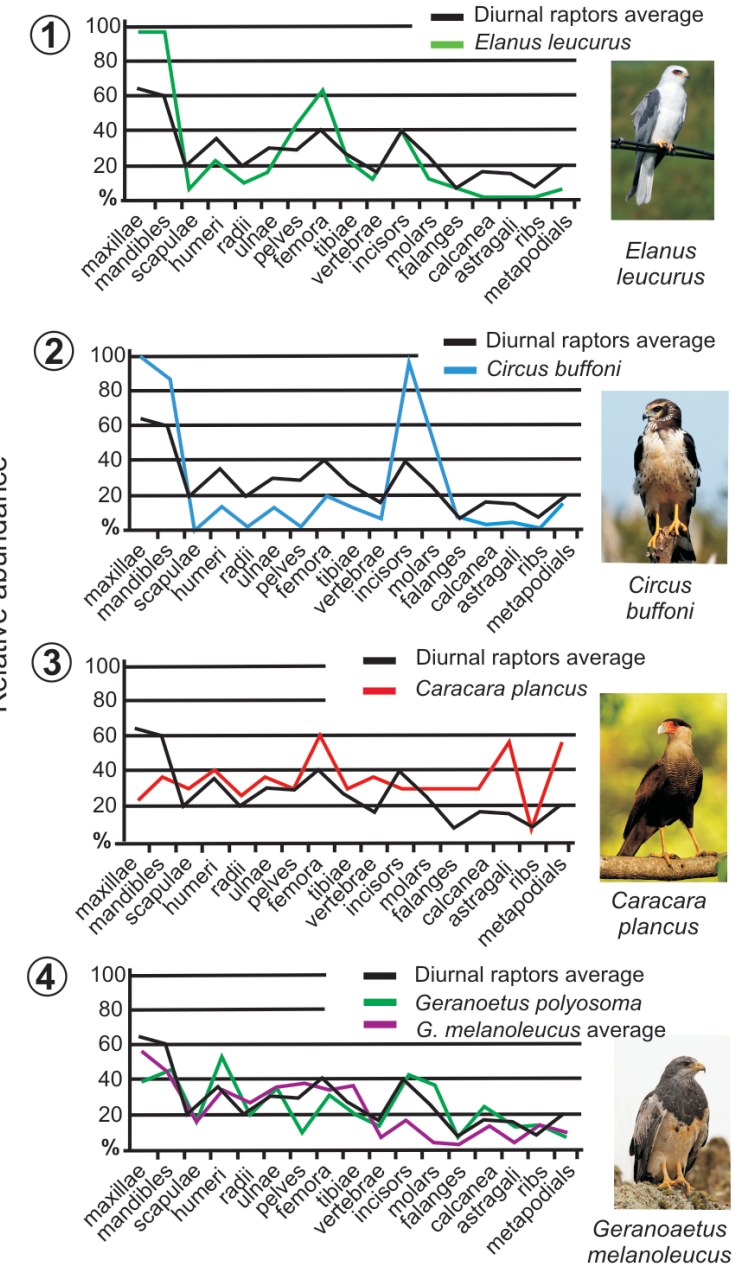

Figure 8. Relative abundance of different South American diurnal raptors compared with their total average. 1, Elanus leucurus (Accipitridae; Montalvo et al., 2014); 2, Circus buffoni (Accipitridae; Gómez, 2007); 3, Caracara plancus (Falconidae; Montalvo and Tallade, 2009); 4, Geranoaetus melanoleucus (Accipitridae) average of samples from López et al. (2017a), and G. polyosoma (López et al., 2017a).
(Montalvo et al., 2014). The highest variability was obtained for the samples of $G$. melanoleucus, with all the skulls and between $30 \%$ to $82.80 \%$ of the mandibles in a broken state; G. polyosoma, in turn, yielded $2.20 \%$ of the skulls and $17.80 \%$ of the mandibles in a complete state (López et al., 2017a).

The samples of diurnal raptors showed a very high percentage of broken postcranials (Fig. 6.2). The highest proportion was recorded for the samples of C. buffoni (Gómez, 2007), which yielded all postcranial elements in a broken state, and of C. plancus, which only presented $18.18 \%$ of the humeri in a complete state (Montalvo and Tallade, 2009).

Degree of digestion. The samples of diurnal raptors (Fig. 7.2) show a strong change in the degree of modification by digestion with respect to that of Strigiformes. The percentage of remains without evidence of digestion diminished with respect to that of previous samples. G. polyosoma showed all the skeletal elements of their prey with signs of modification; C. plancus, 99.8\%, and E. leucurus, 99.0\%. The samples of M. chimango, C. buffoni and G. melanoleucus yielded $25 \%$, $27.2 \%$ and $44.8 \%$ of their remains without signs of digestive action, respectively. In all the aforementioned samples, the percentage of the slight category diminished and that of moderate modifications markedly increased, with only $M$. chimango yielding this kind of modification (50\%) (Gómez, 2007). The diurnal raptor samples that were studied yielded a high percentage of remains with strong and extreme modification. As an example, only in E. leucurus (Montalvo et al., 2014) and C. plancus (Montalvo and Tallade, 2009), the skeletal elements with strong or extreme evidence of corrosion surpass the $10 \%$ of the remains affected by digestion.

\section{Mammalian predators}

Relative abundance and degree of breakage. The average of relative abundance of South American carnivore mammals was of $33.10 \%$ (see Suppl. inf. 2).

Figure 9 shows the comparison of the curves of relative abundance of the carnivore mammal species and their average. The curves of relative abundance are characterized by a good representation of mandibles, maxillae, humeri, femora and isolated teeth, and a low abundance of scapulae, radii, vertebrae, ribs and phalanges. In general, all species of carnivore mammals, including the felids $P$. con- 
color and L. geoffroyi, the mephitid C. chinga, the mustelid $L$. longicaudis and the canid L. griseus, present similar patterns of representativity (Montalvo et al., 2007, 2008b, 2012a, 2015; Gómez, 2007; Gómez and Kauffman, 2007). However, the samples of the marsupial $D$. albiventris yielded higher scapulae and pelves than other mammals (Gómez, 2007).

The samples produced by carnivore mammals yielded broken skulls and mandibles in general. These elements were recorded in a $100 \%$ in the samples of P. concolor (39

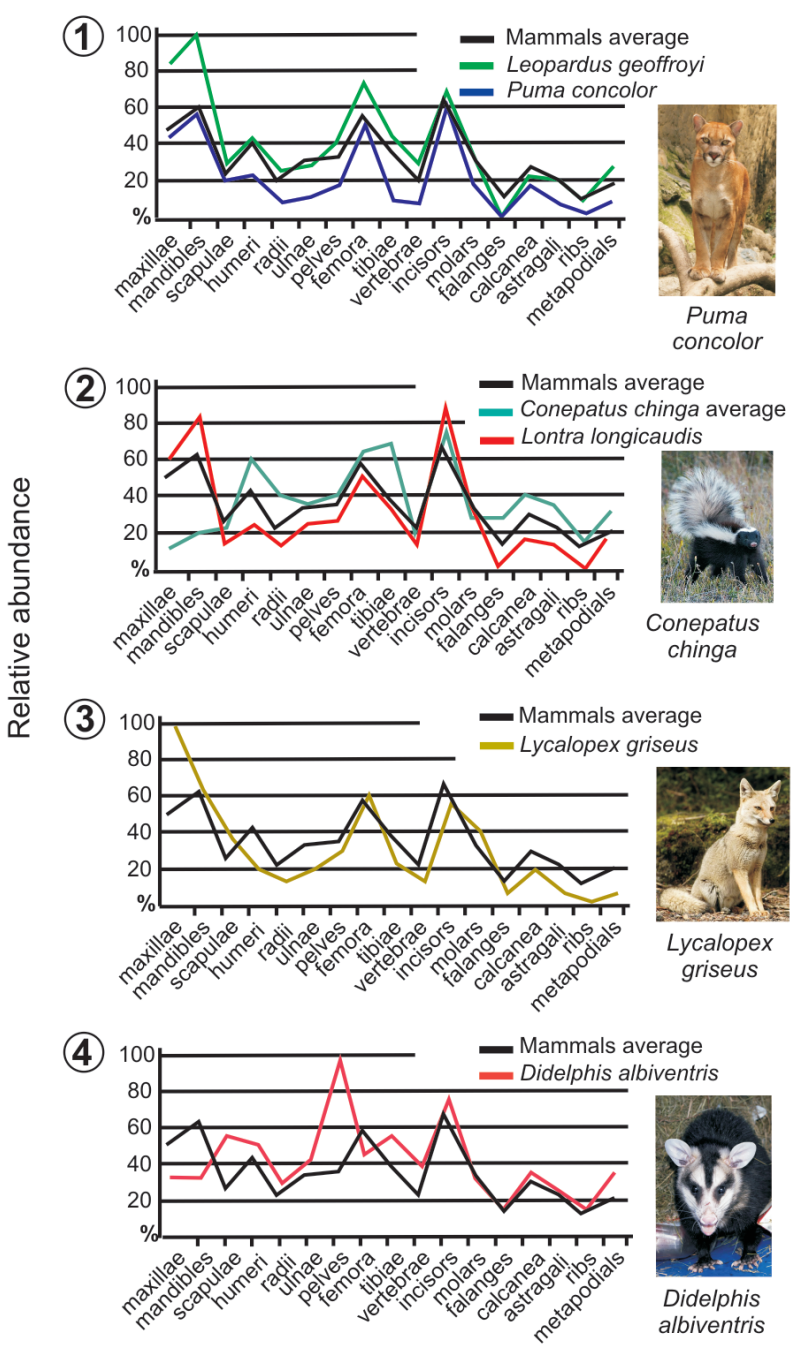

Figure 9. Relative abundance of different South American carnivore mammals compared with their total average. 1, Leopardus geoffroyi (Felidae; Montalvo et al., 2012) and Puma concolor (Felidae; Montalvo et al., 2007); 2, Lontra longicaudis (Mustelidae; Montalvo et al., 2015), and average of Conepatus chinga (Mephitidae; Gómez, 2007; Montalvo et al., 2008); 3, Lycalopex griseus (Canidae; Gómez and Kauffman, 2007); 4, Didelphis albiventris (Didelphidae; Gómez, 2007). scats; Montalvo et al., 2007), P. yaguoaroundi (3 scats; Gómez, 2007), C. chinga (66 scats; Montalvo et al., 2008b) and L. griseus (59 scats; Gómez and Kauffman, 2007). In the sample of L. longicaudis (320 scats; Montalvo et al., 2015), all skulls were broken; yet, $12.16 \%$ of the mandibles were complete.

The aforementioned samples had a low proportion of complete postcranial elements (Fig. 6.3). Ulnae displayed a high degree of completeness in all samples and, for L. longicaudis, only a few humeri were preserved in a complete state (Montalvo et al., 2015) whereas, for C. chinga, a few femora and ulnae proved complete (Montalvo et al., 2008b). In this case, no significant differences were observed in the degree of breakage in relation with the body mass of the predator.

Most of the studied carnivore mammals included remains with teeth marks produced during chewing.

Degree of digestion. The accumulations produced by carnivore mammals yield higher percentages of modifications by digestion (Fig. 7.3). Only the sample of $D$. albiventris yielded $38.7 \%$ of its remains free of evidence of digestion, whereas those of $P$. yagouarondi and $L$. griseus yielded $22.4 \%$ and $6.2 \%$, respectively. The samples of the other predators yielded very few remains -or even none- without evidence of modifications. In P. concolor $(0.6 \%)$, C. chinga $(0.1 \%)$ and, finally, in L. geoffroyi, all the remains were digested. Concerning these predators, there was an increasing proportion of skeletal remains with evidence of strong and extreme digestion. The latter type was observed in all samples, although the percentage of affected remains is variable among different predators, v.g., maximum $30 \%$ in P. concolor (Montalvo et al., 2007) and minimum 4\% in D. albiventris (Gómez, 2007). Even with the characteristics so far described, all the accumulations yielded important percentages of skeletal elements of the slight category, with a maximum of $37.9 \%$ in L. griseus (Gómez and Kauffman, 2007). Thus, in accumulations produced by carnivore mammals, many remains showed modifications by digestive acids, from all the proposed categories, but with similar percentages of remains in the moderate and strong categories.

\section{Comparison with non-South American predators}

Raptors. The greatest interest in actualistic and fossil taphonomic studies of different regions of the world was focused 
on the nocturnal raptor T. alba (Dodson and Wexlar, 1979; Hoffman, 1988; Andrews, 1990; Kusmer, 1990; Denys et al., 1996; Pokines and Kerbis Peterhans, 1997; Saavedra and Simonetti, 1998; Bruderer and Denys, 1999; Terry, 2004; Reed, 2005; Broughton et al., 2006; Andrade, 2015; Fernández and Montalvo, 2017; Denys et al., 2018). This is because this raptor regularly uses caves or rocky refugees, and leaves all pellets in the area (Southern, 1954). In addition, this predator produces slight modifications and, thus, the prey remains are in good state and can be used as samples of the micromammals of the area. The accumulations produced by $T$. alba, when analyzed from a taphonomic point of view, were compared with other samples of this predator from different regions of the world (e.g., Hoffman, 1988; Andrews, 1990; Kusmer, 1990). The results of these comparisons yielded some differences between the samples from South America and those recovered from different places of North America, Europe and Africa (e.g., relative abundance, digestion).

The comparison of the relative abundance average of South American nocturnal raptors with that which was reported by Andrews (1990) $-46.54 \%$ and $42.95 \%$, respectively - shows similar values for most skeletal elements, except for maxillae, mandibles, scapulae and incisors (Fig. 10.1). This variability could be due to taxonomical differences in the represented rodent taxa (their estimated body masses in particular). Although Andrews (1990) stated that prey size cannot be considered as a diagnostic character for a predator and, moreover, that predators take what they can and is available in their environment, South American predators could more frequently ingest rodents of greater body mass. Particularly, we think that body mass plays a main role in this sense because the bones of larger rodents may be more affected by breakage and loss than those of smaller body mass rodents.

Probably, not taking into account one of the biases produced by taxonomic representations among samples from different continents as a key element is one of the reasons that explain these differences. As an example, we can mention the differences observed in the T. alba samples from province of Mendoza that were studied by Iglesias (2009) and Fernández et al. (2009a), or the evaluation of the natural and experimental samples of the province of Buenos
Aires (Gómez, 2007; Quintana, 2015) when compared with actualistic ones from Europe and Africa drawn by Andrews (1990) (Fig. 11.1). These reasons justify the need for more evaluations of T. alba samples, in which emphasis is focused on the differences in the results according to the area and time of collection, which are ultimately, according to the types of ingested prey, as already stated by Saavedra and Simonetti (1998).

In this group of South American raptors, breakage values are consistent with those of Andrews (1990) for Strigiformes, who also placed T. alba among the predators that produce less destruction of cranial elements, as seen in the South America samples.

There are some differences between the average of relative abundance of diurnal raptors from South America (26.05\%) and that which was reported by Andrews (1990) for diurnal raptors of different places of North America, Europe and Africa (34.47\%) (Fig. 10.2). In general, the values proposed for South American species are lower, except for vertebrae and metapodials. Even though, in general, the pattern of peaks in the averages of both samples is maintained, which points out similarities in maxillae, mandibles, humeri, femora and incisors, in both cases, vertebrae, phalanges, calcanei, astragali, ribs and metapodials show low average values. The differences in the representation of some skeletal elements and averages could be related to the loss of the most fragile (scapulae, radii, ulnae) or smallest (autopodial elements, vertebrae, ribs) bones.

Several of the predator species herein evaluated correspond to genera also represented in the Northern hemisphere. The evaluations of these taxa were used to compare results and point out similarities and differences among the samples from different continents and species. For example, the sample produced by E. leucurus, from the province of La Pampa (Montalvo et al., 2014), was compared with the sample produced by Elanus caeruleus (Desfontaines, 1789), from northern Africa (Fig. 11.2; Souttou et al., 2012). The samples from Argentina and Algeria showed some differences regarding anatomical representation and, also, in the percentage of breakage (PF= total number of bones/number of broken bones) of the different skeletal elements. E. leucurus showed a higher proportion of bone breakage (Montalvo et al., 2014: fig. 4). These differences may be attributed 
to postdepositional processes such as weathering or trampling (Fig. 11.2).

The sample of $B$. v. magellanicus, from the province of Mendoza (Montalvo et al., 2016b), was compared with those of other species of Bubo [Bubo lacteus (Temminck, 1820), Bubo africanus (Temminck, 1821) and Bubo bubo (Linnaeus, 1758)] from Africa and Europe (Andrews, 1990; Lloveras et al., 2009, 2012). In this case, some differences in terms of anatomical representation were observed (Fig. 11.3); yet, in all samples, there were peaks in mandibles, humeri and femora and a low representation of scapulae, vertebrae, teeth and ribs. However, Montalvo et al. (2016b) suggested

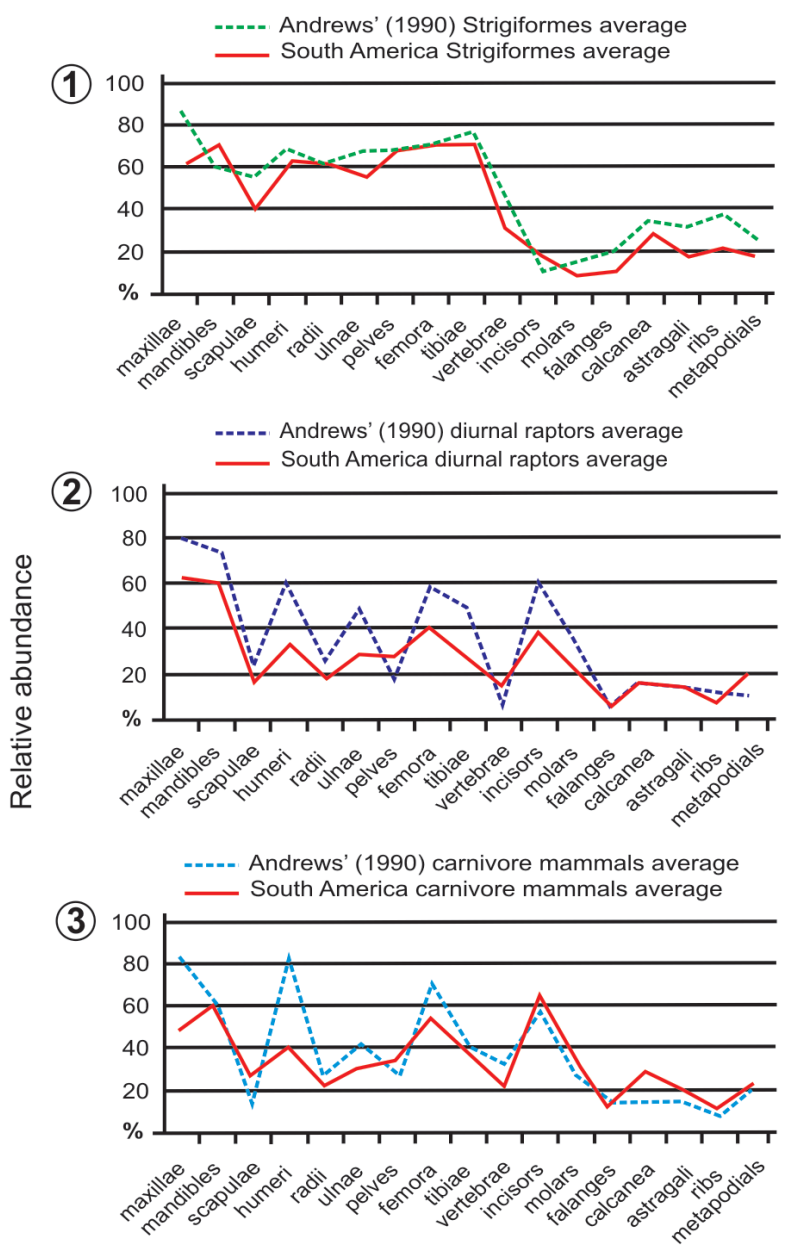

Figure 10. Comparison of the averages of the relative abundance reported by Andrews (1990) with our study of: 1, South American Strigiformes species; 2, diurnal raptor species (Falconiformes and Accipitriformes); and 3, carnivore mammal species. that their anatomical representation results in a typical 'owl' pattern (Andrews, 1990).

Carnivore mammals. There is more information about the modifications produced in the bones of their prey for species of large, medium and small-sized carnivore mammals under-studied from a neo-taphonomic point of view (Campmas et al., 2018). The comparison of the average of the relative abundance of South American carnivore mammals (33.10\%) with the one reported by Andrews (1990) (27.34\%) shows similarities in the mean peaks of femora and incisors.

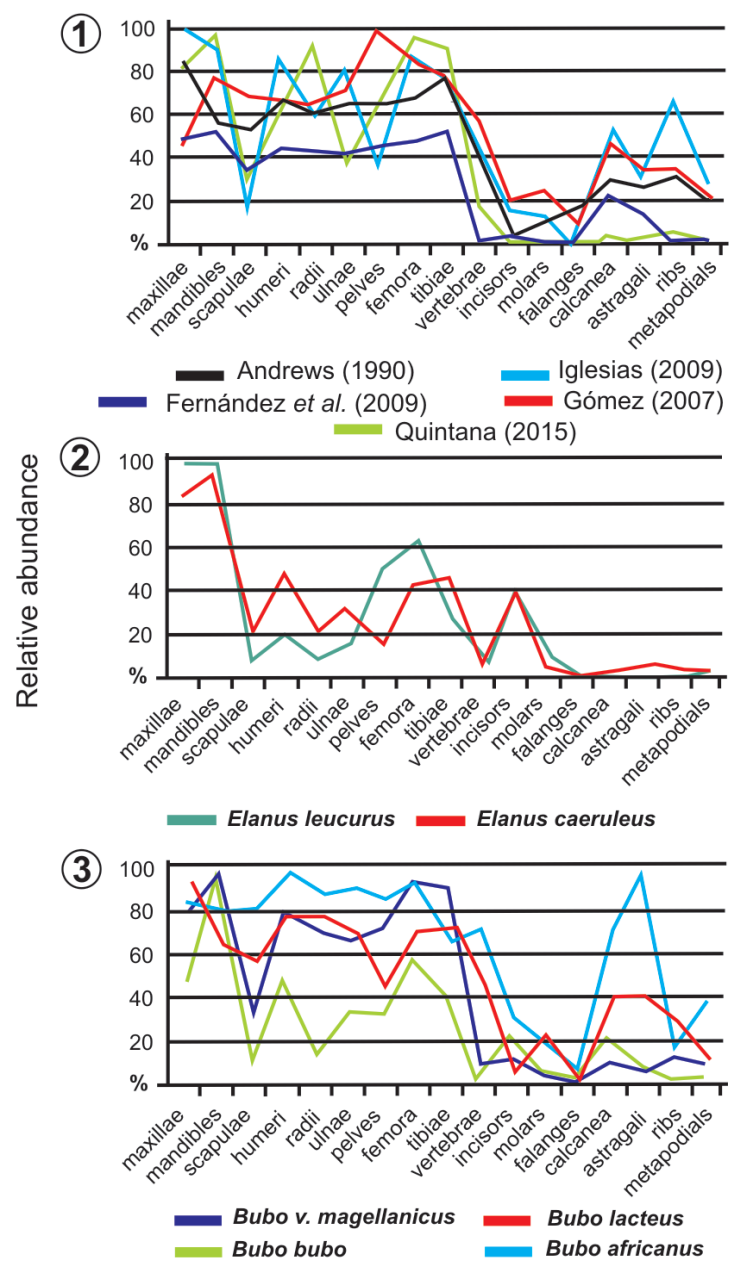

Figure 11. Comparison between some South American predators and representatives of each group in other regions of the world. 1, Tyto alba South American samples compared with Andrews (1990) data; 2, Argentinean Elanus leucurus sample compared with Algerian Elanus caeruleus sample; 3 , Bubo virginianus magellanicus sample compared with samples of different species of Bubo described by Andrews (1990). 
But the average representativity of maxillae and humeri is much lower (Fig. 10.3). Regarding the carnivore mammals, those genera that produced the studied samples have representatives throughout the American continent, but there is no other information about how they modify the bones of the small mammals they ingest.

Andrews (1990) stated that the samples from carnivore mammals showed no complete skulls and could be placed in the same breakage category than diurnal raptors and mammalian carnivores. However, in the South American samples (Fig. 6.2-3), the diurnal raptors show a lower percentage of complete elements than carnivore mammal species. Results obtained for South American carnivore mammals are consistent with those of Andrews (1990), among which, there is a high degree of destruction of the skeletal elements.

\section{Re-evaluation of the methodology for the study of small mammal assemblages}

The comparison among South American samples and those from North America, Africa and Europe made by Fernández et al. (2017) yielded similarities and differences in digestive corrosion of incisors and molars (Figs. 12-13). The main results of those researches are summarized in the following items: 1) the morphology of the incisors of Caviinae, Abrocomidae and Sigmodontinae proved similar to that of rodent groups of North America, Europe and Africa (Arvicolinae and Muridae); 2) because the incisors of Ctenomyidae had a wider labial surface and a thicker enamel, a delay in the appearance of digestion was observed when compared with other rodent incisors; 3) the categories of digestive corrosion of Monodelphini teeth showed similar characteristics to those observed in the insectivores Talpi-

\section{Light}

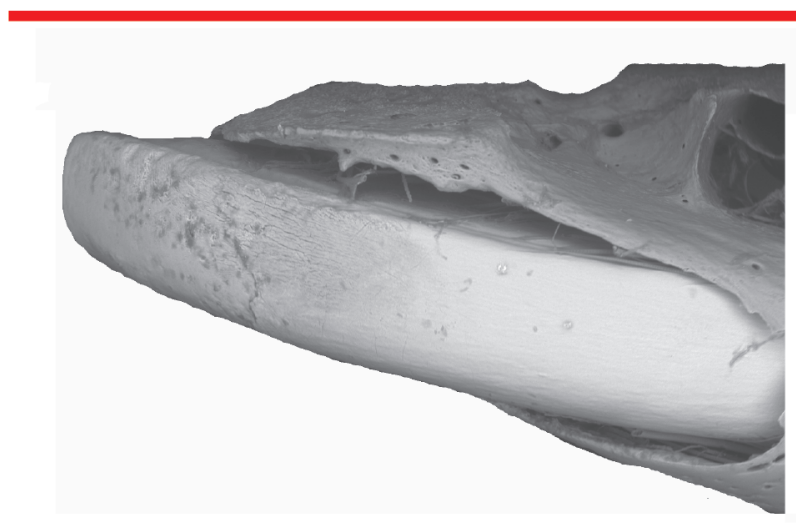

Heavy

\section{Moderate}

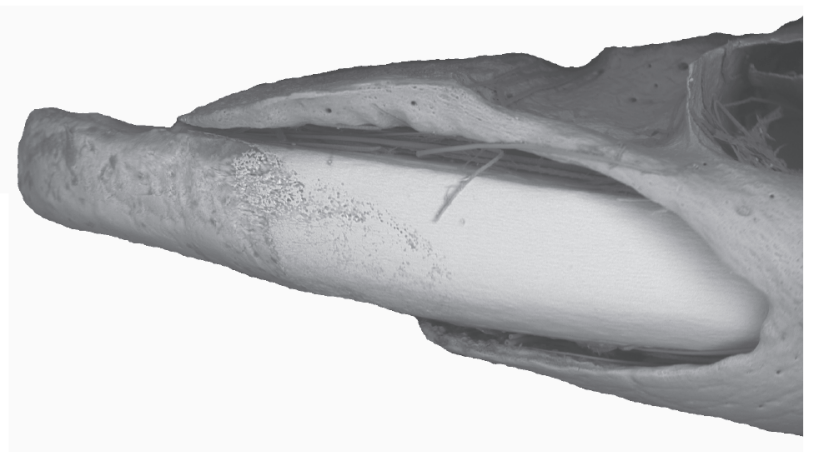

Extreme

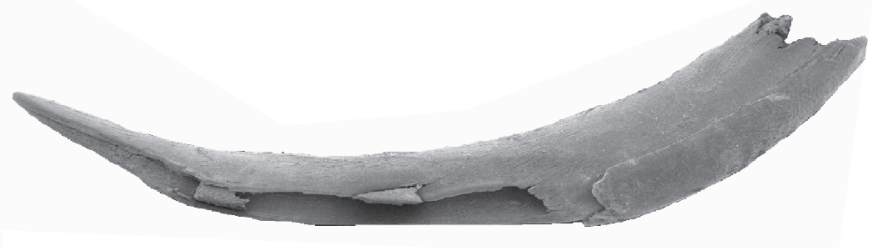

Figure 12. Examples of digested incisors from South American rodents. Not in scale. Several photos used with $\odot$ Elsevier permission (License number 4424850517897). 
dae, Soricidae and Erinaceidae; 4) a delay of evidence of digestion was recorded in Soricidae molars, which is consistent with the presence of a thick and continuous layer of enamel that provides resistance to corrosion; the categories of digestive corrosion of Caviinae and Abrocomidae show

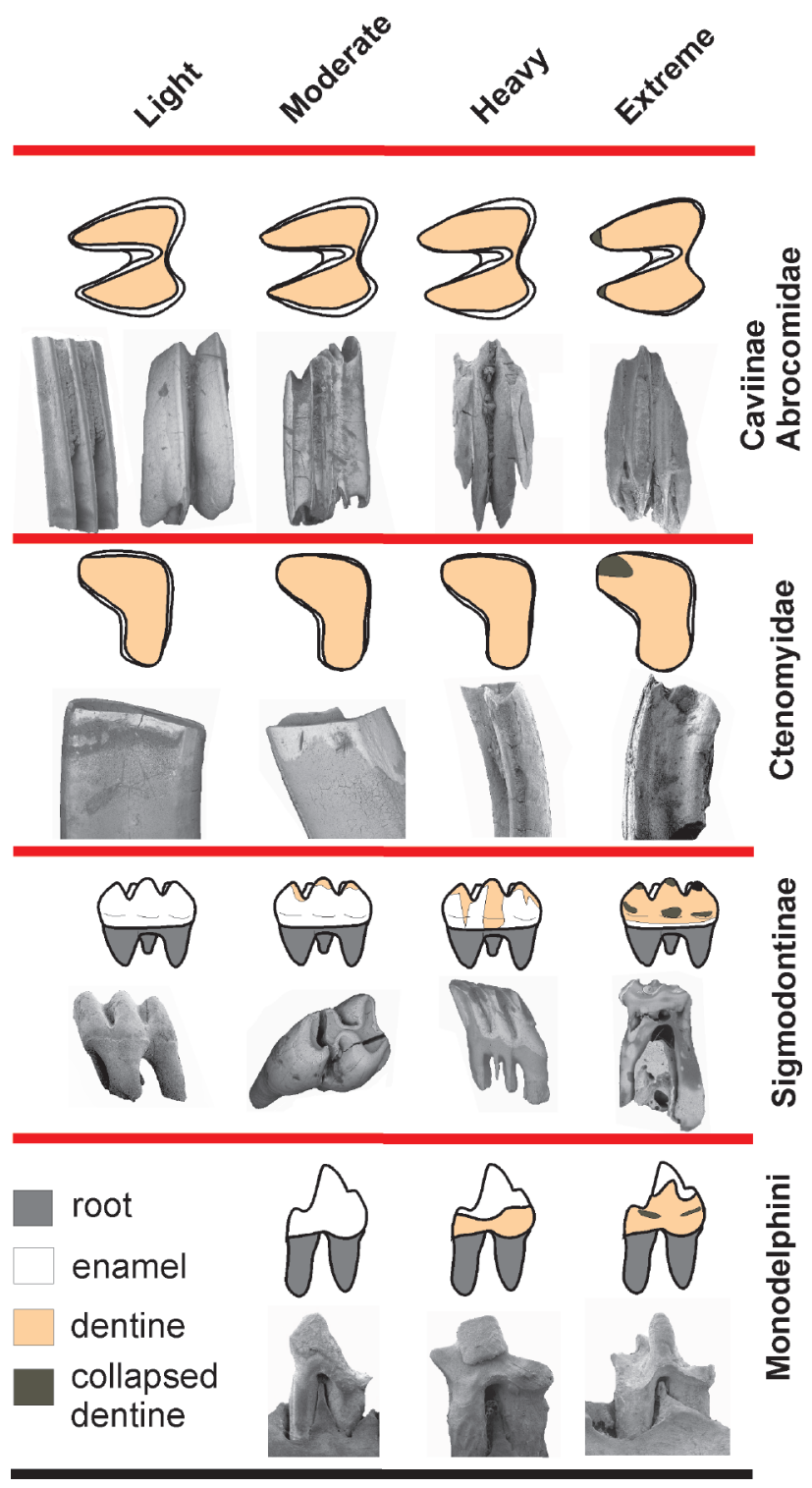

Figure 13. Scheme of categories of digestion of molars for Caviidae, Ctenomyidae, Sigmodontinae and Monodelphini. The shape and enamel thickness of the tooth produce different responses to the effects of digestion (see the text). Design based on the original Stoetzel (2009) and Fernández et al. (2017) schemes. Not in scale. Several photos of Caviinae, Sigmodontinae and Monodelphini used with $\odot$ Elsevier permission (License number 4424850517897). features that are similar to those of Arvicolinae; 5) the molars of Caviinae present abundant cement protuberances on the enamel, and the digestive corrosion easily removes these protuberances and produces numerous striated depressions; 6) the categories of digestive corrosion of Sigmodontinae molars have similar characteristics to those of Muridae; 7) however, the molars of some tribes of Sigmodontinae (e.g., Akodontini, Abrotrichini), with a high degree of wear in senile individuals, exhibit a thin radial enamel and inner exposed dentine. Therefore, the enamel can be quickly removed and separated from dentine by the effects of digestion; 8) the thick radial enamel of Ctenomyidae gradually exhibited evidence of corrosion; from a light and moderate pitting to the thinning or loss of enamel walls (continuously or in patches); 9) the enamel of digested molars of Caviinae and Abrocomidae is removed at the earliest stage of a light category of digestion, and Ctenomyidae and Sigmodontinae, accompanying the former small mammal groups, show digestion traits only at a moderate category whilst Monodelphini start showing signs of digestion when Caviinae and Abrocomidae are already affected at heavy grades of digestion. In other words, pellets of a category 1 predator may contain Caviinae and Abrocomidae molars affected in a light degree with enamel removal from the salient angles of prisms (similar to Arvicolinae), Ctenomyidae molars showing a light pitting in the occlusal surface, Sigmodontinae molars with a matt enamel surface and more rounded cups (like Murinae) and Monodelphini molars showing no digestion signs (similar to Soricidae).

The small mammals considered in Fernández et al. (2017) included Ctenomyidae, Caviinae, Sigmodontinae and Monodelphini, which are distributed throughout almost all South America. Nevertheless, we consider the continued evaluation of other groups not included in that research (e.g., Octodontidae, Echimyidae) and the extension of the study of predators that are endemic to this geographical area essential.

\section{Categories of small mammal modifications for South American predators}

The previous results gather data of the studied South American predators and compare it with those which had been reported by different authors (Suppl. inf. 1).

A correspondence analysis yielded coherent values 
grouping the nocturnal raptor (Strigiformes) samples with low values of modification and separating them from the samples of diurnal raptors (Accipitriformes and Falconiformes) and mammals (Felidae, Canidae, Mephitidae, Mustelidae, Didelphimorphia) with known high values of modification (Fig. 14). However, it highlighted that the main factor (axis 1, $\sim 62 \%$ of the variance) shows that the sample of $G$. melanoleucus is close to those of nocturnal raptors.
Contrarily, the sample of the felid $P$. yaguaroundi is the farthest (Fig. 14).

Figure 15 shows a ternary diagram built on the proportions of the most relevant taphonomic attributes. The sample of T. alba appears isolated with a combination of high values of relative abundance of elements and low values of breakage and digestive corrosion. The other strigiforms are grouped, but with some differences. For instance, samples

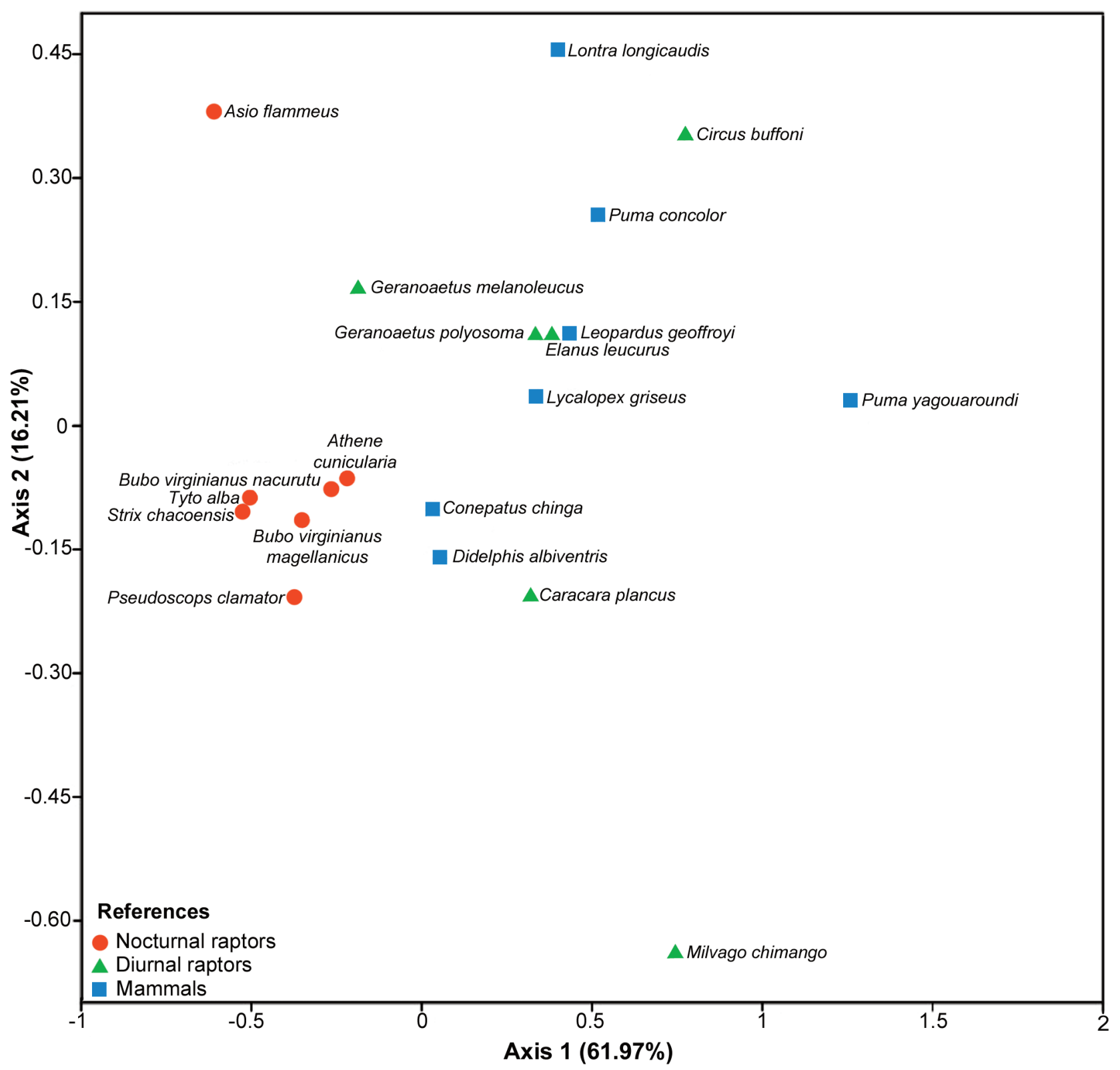

Figure 14. Correspondence analysis of small mammal assemblages yielded by the studied predators. Percentages of both axes show the variance. 
of B. v. nacurutu and A. cunicularia display major levels of breakage and digestive corrosion, respectively. In addition, S. chacoensis presents an intermediate position in this group. On the other hand, diurnal raptors and mammals form a closer group with higher values of digestive corrosion and breakage, and lower values of relative abundance. In this case, the ternary diagram shows less variation than the correspondence analysis, apparently because less taphonomic attributes were taken into account and corrosion values were synthesized into a single category.

Both statistical analyses (Figs. 14-15), along with the taphonomic attributes that had been separately analyzed in the previous sections, enabled the adjustment, through large comparisons, of the modification of the categories indicated in the original papers (Suppl. inf. 1).

The data herein revised and assessed suggest that South American predators may be gathered into four categories of modification (see Suppl. inf. 3). In this context, they were grouped as predators causing: 1) light (T. alba, Bubo spp. and $A$. flammeus); 2) moderate ( $A$. cunicularia, S. chacoensis and $P$. clamator); 3 ) heavy (C. buffoni, Geranoaetus spp., C. plancus, E. leucurus and L. geoffroyi); and 4) extreme (M.

\section{References \\ Nocturnal raptors \\ Diurnal raptors \\ Mammals}

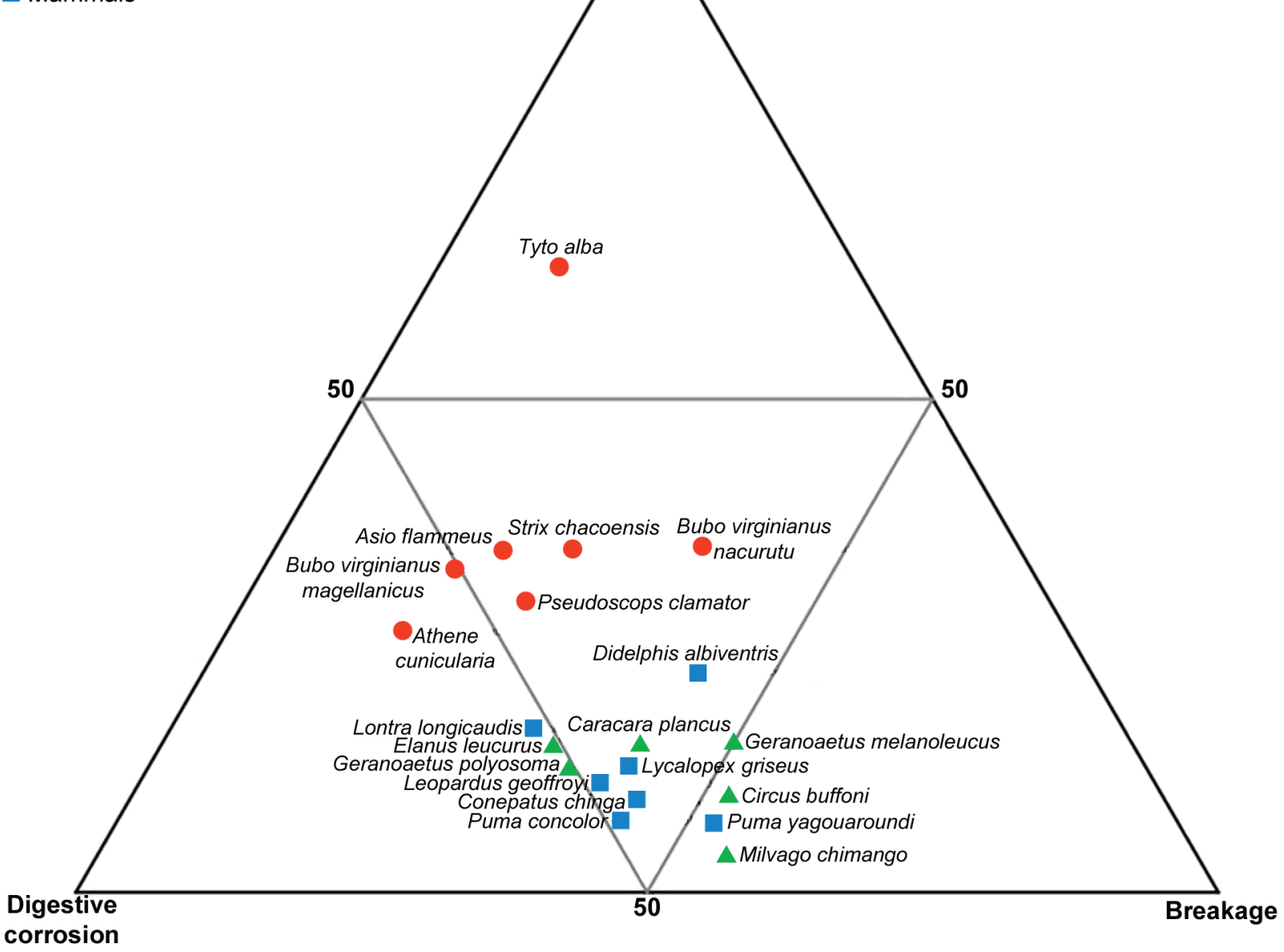

Figure 15. Ternary diagram based on proportions of average of relative abundance, digestive corrosion and breakage of the small mammal assemblages yielded by the studied predators. 


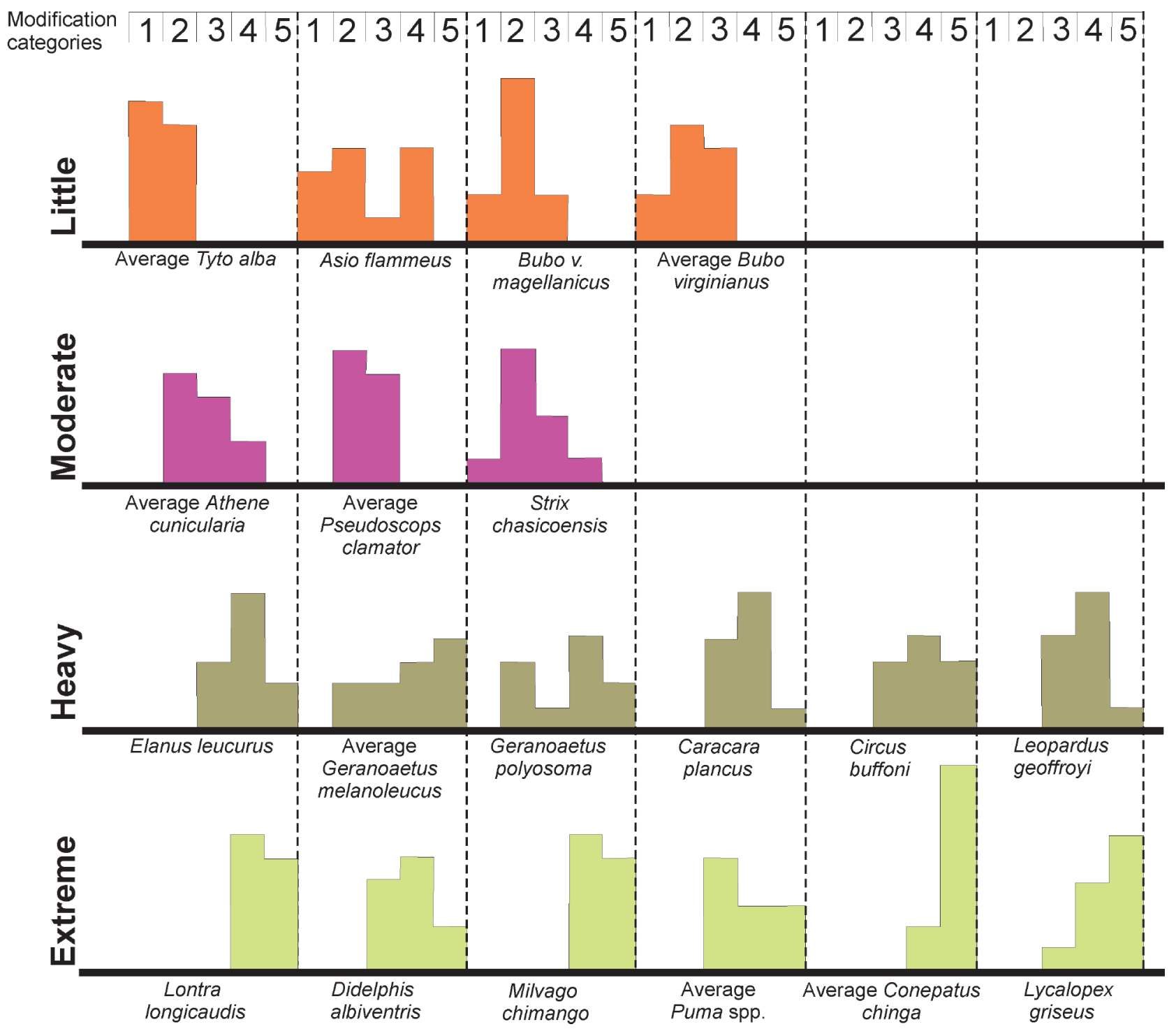

Figure 16. Summary of revised predator categories of South American raptors and carnivore mammals analyzed in this paper.

chimango, Puma spp., D. albiventris, C. chinga, L. longicaudis and $L$. griseus) modifications. All predators grouped in a light category of modification are Strigiformes. The moderate category includes Strigiformes and Accipitriformes. There is no clear evidence of the intermediate category in South American predators (as was proposed by Andrews, 1990). The heavy category embraces Accipitriformes, Falconiformes and several species of carnivore mammals. Finally, the extreme category comprises one species of Falconiformes and several species of carnivore mammals. In this sense, South American diurnal raptors and carnivore mammals are included in the greater categories of modifications (heavy and extreme) (Fig. 16).

\section{THE APPLICATION OF SMALL MAMMAL FOSSIL RECORDS IN SOUTH AMERICA}

Efremov (1940), when creating the word taphonomy and its definition, introduced the principle of actualism to interpret past records. As already stated, predation is the 
main factor in accumulating small vertebrate assemblages both in modern and in fossil sites (Andrews, 1990; Fernández-Jalvo and Andrews, 1992; Gómez, 2005, 2007; Matthews, 2006; Verzi et al., 2008; Fernández-Jalvo et al., 2016). Accumulations of small vertebrates and, especially, of small mammals, produced by predation, may be recognized by the presence of digestion on their teeth and skeleton.

We are interested in those fossil assemblages whose origin may be explained through biological action. In this context, field observations during the collection of the fossil or archaeological remains must be supported by detailed descriptions of the bearing levels. Geological, geomorphological and environmental contexts can help to understand the mode of occupation of the sites (e.g., roosting, nesting and hunting possibilities). These observations will help in the interpretation of the taphonomic history of an assemblage and the understanding of the taphonomic context of a palaeontological or archaeological site.

As the fossil accumulations that can be interpreted as a result of predation become older, the difficulty to interpret the possible predators through the evaluation of their prey increases. In Argentina, actualistic analyses turned out to be very useful and have allowed us to adjust the possible predators up to the species level when evaluating zooarchaeological records (Pardiñas, 1999b; Fernández et al., 2009a; Fernández, 2012; Montalvo et al., 2014; Quintana, 2016a,b; López et al., 2017a, 2018; Mignino et al., 2018) or palaeontological accumulations from the Pleistocene and Holocene (Pardiñas, 1999b; Pardiñas et al., 2000; Montalvo et al., 2012b, 2017; Tomassini et al., 2017).

\section{Palaeontological sites}

When fossil accumulations are older, problems in the interpretations may arise. Postdepositional processes that may usually affect the remains create biases that hamper the primary nature of the assemblage. Among others, breakage and loss of skeletal elements, weathering, corrosion and adhesions can hide modifications by digestive action. In addition, several features observed in digested bones, such as rounding and polishing, are similar to the rounding and polishing produced by other processes, particularly abrasion, in which predation is not involved (Fernández-Jalvo et al., 2014). Identifying all the processes post-accumulation by predation (or at least most of them) helps to distinguish the characteristics imposed by the possible predators, as well as others that have subsequently affected the bones.

The identification of pellets and scats recovered from fossil deposits was simpler when they preserve some of their original morphology or even for bone remains with evidence of digestive corrosion that can be linked with a predator. These kinds of accumulations were described for pellets found in the Pliocene Monte Hermoso Formation (province of Buenos Aires), which contained bone remains with strong evidence of digestion, and in Pleistocene pellets from the Quequén Salado river (province of Buenos Aires) and others related with the Holocene fluvial deposits of the Quehué Valley (province of La Pampa) assigned to nocturnal raptor birds (Tomassini and Montalvo, 2010; Montalvo et al., 2012b, 2017).

Another problem that must be taken into account when studying microvertebrate accumulations from times older than the Pleistocene is related with the taxonomic diversity of South American predators and prey. With respect to the latter, it has been already stated that actualistic taphonomic studies dealing with non-mammal vertebrates are scarce. Denys et al. (2018) evaluated all the prey consumed by $T$. alba (birds, rodents, shrews, amphibians and insects). These authors compared bone representation, fragmentation and digestion for each taxon. They observed differences among the studied taxa; yet, they also found major differences in the remains of this multitaxa sample when compared with samples of $T$. alba from other regions. These authors suggested that all prey must be evaluated in order to use this modern analog when studying accumulations of the fossil record. As another example, Royer et al. (2019) evaluated small vertebrate accumulations produced by the snowy owl [Bubo scandiacus (Linnaeus, 1758)]. This owl can hunt many different small vertebrates, although lemmings constitute one of their preferred prey. This study shows very different sizes of prey consumed by snowy owls. The authors observed high inter-site variability for some of the considered alterations (in particular, digestion on incisors) and major modifications than in previous papers that analyzed samples produced by this owl (Royer et al., 2019). In this case, multitaxa accumulation studies help suggest a new cate- 
gory for this predator. However, going backward in geological time, the accumulations in South America are formed by small mammals without current representatives, which baffles their use of current analogs. An example of this issue is the abundance of remains assigned to Paedotherium Burmeister, 1888 (Notoungulata, Hegetotheriidae) in the Neogene of central Argentina (Cerdeño and Bond, 1998; Sostillo et al., 2018). In many sites, the remains of this taxon are part of assemblages that may be related with predation (Montalvo, 2004); however, there is no modern analog with similar dental morphology -molariforms externally covered by a thick cement layer-. In the taphonomic evaluation of these assemblages, which include many remains of this taxon, the question of whether the variability observed in the external characteristics of that external cement (thinning, peeling, pits) in the different specimens may correspond to digestive differences arises. Additionally, in the case of fossil assemblages, remains of small mammals with a very small body mass are either absent or only represented by a few skeletal elements or exclusively by isolated teeth, which obscures their evaluation. For example, in the Miocene assemblage of the Cerro Azul Formation in Estancia Ré (province of La Pampa), from 597 specimens assigned to different small mammals, $56 \%$ correspond to remains of Paedotherium and other small notoungulates while only $14 \%$ correspond to representatives of Didephimorphia and Rodentia with very small body masses; the remaining specimens correspond to larger rodents and indeterminable remains (Montalvo et al., 2016c). These proportions show a bias in the representativeness of the skeletal elements of taxa with different body masses.

This kind of drawback related with the taxa of the fossil record also occurs when evaluating predators. The orders that include taxa from which current taphonomic studies were drawn are very poorly represented in the South American fossil record. Representatives of Strigiformes and Falconiformes birds are recorded since the Early Miocene of the Pinturas Formation (province of Santa Cruz), and Accipitridae, since the Early and Middle Eocene of the Musters Formation, province of Chubut (Tambussi and Degrange, 2013). Among mammals, representatives of Didelphimorphia are recorded in South America since the Late Cretaceous. The history of mammals from the continental Order
Carnivora in South America is relatively recent (Late Miocene) and closely related with the Great American Biotic Interchange. The fossil record of small South American felids and mephitids is poor; the first ones are recorded since the Ensenadean (Early Pleistocene), whereas the first canids and mustelids, since the Vorohuean (Late Pliocene) (Cione et al., 2015).

We have not discussed it in detail here, but it is noteworthy that many of the South American predators, including several of the ones hereby analyzed, ingest part of their prey and leave other sectors as remains of prey. This behavior has been observed in several eagles, raptors and mammal predators, and important amounts of their prey skeletal remains are thus accumulated (Álvarez et al., 2012; Lloveras, 2017; Lloveras et al., 2018 and literature therein). This implies a double entry for these predators, through the bone remains ingested and accumulated in pellets or scats on the one hand, and from the remains of undigested prey on the other hand, which are generally accumulated in the vicinity of nests or caves. Only a few works have dealt with this problem so far and they have done so by characterizing and comparing the two types of remains. As background, we can mention the ingested remains and the abandoned remains of prey produced by Buteogallus coronatus (Vieillot, 1817) (Montalvo et al., 2016a; Galmes et al., 2015) and C. plancus (Montalvo and Tallade, 2009). These comparisons helped the authors discern the characteristics of some Late Miocene sites of the province of La Pampa, in which each faunal assemblage was interpreted as the accumulation of non-ingested prey remains of carnivore mammals and led them to propose a new taphonomic mode, termed "leftover prey remains" (Montalvo et al., 2016c).

In some cases, the taphonomic interpretation of a fossil assemblage could be hindered due to the possible existence of extinct predators, which prevents the possibility of having a reliable actualistic model. For example, Nasif et al. (2009) studied a Late Miocene pellet sample from the Andalhuala Formation (northwestern Argentina). The authors stated that the pellets were deposited by the so-called "terror birds", small predators (Phorusrhacidae, Psilopterinae), taking into account that these extinct birds were the only predators identified in the Andalhuala Formation. 


\section{Archaeological sites}

The South American archaeological sites encompass a much shorter period than palaeontological ones, from the end of Late Pleistocene to historical times; thus, the preservation of small mammal remains, and even the finding of pellets and scats, are more frequent (e.g., Crivelli Montero et al., 1996; Pardiñas, 1996-1998, 1999a,b; Fernández and De Santis, 2013; Fernández et al., 2012, 2015; 2016a,b; Fernández and Pardiñas, 2018). Taphonomic studies arising from the study of these sites, with special attention to the activity of raptors and mammals as accumulator agents, began during the mid- to late 1990s and continue to grow exponentially up to the present, mostly in Argentina. The main groups of specialists focused their taphonomic researches on the humid Pampa (e.g., Pardiñas, 1999a,b; Scheifler et al., 2012, 2015; Quintana, 2016a,b), central Argentina (e.g., Mignino, 2017; Mignino et al., 2018), central west Argentina (e.g., Fernández et al., 2009a, 2015; Fernández, 2012; Montalvo et al., 2016b; López et al., 2016, 2017a, 2018; Fernández and Pardiñas, 2018), northwestern Argentina (e.g., Ortiz and Pardiñas, 2001; Ortiz and Jayat, 2007) and Patagonia (e.g., Crivelli Montero et al., 1996; Pardiñas, 1996-1998, 1999a,b; Fernández et al., 2011, 2012, 2016a,b; Andrade, 2015). However, the predator taphonomy model of Andrews (1990), Fernández-Jalvo and Andrews (1992), and Fernández et al. (2017) has had a low impact on the studies of small mammal assemblages from archaeological sites of other countries of South America. For example, in central Chile, these kinds of studies also followed the growing trend of the mid to late 1990s and prolonged into the early 2000s (Simonetti and Cornejo, 1991; Saavedra, 1994; Saavedra and Simonetti, 1998, 2003) yet unfortunately lost continuity and practically do not exist at present. In addition, these works are focused on the human exploitation of caviomorph rodents without paying attention to the predators of sigmodontine rodents. In the high Andes of Bolivia, Pokines (2014) studied three Late Holocene deposits with small mammals from a taphonomic point of view but without a strict application of the taphonomic methodology of Andrews (1990). In southern Brazil, Stutz et al. (2017) studied the small mammal assemblage from the archaeological site Garivaldino (Early and Mid-Holocene) from a biogeographic and palaeoenvironmental point of view and considered the general aspects of its taphonomic structure. However, this material and others from nearby archaeological sites (Pilger and Sangão) are evaluated (Fernández et al., 2019).

Notably and with only a few exceptions, in most of the archaeological sites, T. alba was the main responsible of the small mammal deposits, especially in cave-type sites. Other owls such as B. v. magellanicus and S. chacoensis, from central west Argentina, were identified as accumulator agents in parts of the archaeological sequences of Laguna el Sosneado-3 and Rincón del Atuel-1, respectively (Montalvo et al., 2016b; López et al., 2018). In the same region, the accipitriforms G. melanoleucus and G. polyosoma were recognized as taphonomic accumulators in the archaeological sites of Rincón de Los Helados, Arroyo Malo-3 and Cueva Palulo (López et al., 2017a). Carnivore mammals (possibly the felid $P$. concolor) were also identified in western Mendoza, Argentina (part of the sequence of Cueva Arroyo Colorado; Fernández et al., 2009a), and in Patagonia (part of the sequence of Angostura 1; Fernández et al., 2011).

\section{FINAL REMARKS}

The average of the relative abundance of elements produced by South American nocturnal raptors was of $42.95 \%$, similar to those species of Andrews (1990). These values of breakage yielded by Strigiformes are also consistent with those of Andrews (1990) for these raptors, which also placed T. alba among the predators that produce less destruction of cranial elements, as seen in the South American samples. The predominant category in the samples of Strigiformes is that of light digestion. The good skeletal elements representation, the scarce breakage of the prey bones and the light modification produced by the digestive acids of the bones accumulated by predators and others that cause light modifications make them good candidates to produce accumulations that are preserved in the palaeontological and archaeological records.

The average in the relative abundance of South American diurnal raptors was of $26.05 \%$, lower than the average reported by Andrews (1990). Although with some differences, all raptor species display a similar pattern. Among diurnal raptors, the degree of breakage of skulls and mandibles was higher than in Strigiformes. Diurnal raptors 
present a strong change in the degree of modification by digestion with respect to that of Strigiformes. For their features, these types of accumulations were more difficult to identify in the fossil record than those of the samples produced by Strigiformes.

The average of the relative abundance of South American carnivore mammals was of $33.10 \%$, similar to that of the species of Andrews (1990). The samples produced by carnivore mammals yielded broken skulls and mandibles in general. These samples had a low proportion of complete postcranial elements. The accumulations produced by carnivore mammals yield high percentages of modifications by digestion, mainly moderate and strong. In several cases, marks produced by teeth helped with the interpretation in the fossil record.

The data drawn from South American predators herein revised and assessed suggest that four categories of modification can be gathered (light, moderate, heavy and extreme). The predators that cause light modifications are T. alba, Bubo spp., S. chacoensis and A. flammeus. Those that cause moderate modifications are $A$. cunicularia, Geranoaetus spp. and $P$. clamator. The predators causing heavy modifications are $C$. buffoni, C. plancus, E. leucurus, D. albiventris, $L$. geoffroyi and L. longicaudis. Finally, the predators causing extreme modifications are $M$. chimango, P. concolor, $P$. yagoauroundi, C. chinga and L. griseus. Several of these predators were evaluated with small samples and their category could be modified with better ones (e.g., D. albiventris).

\section{ACKNOWLEDGEMENTS}

This work was supported by Project 11/N769 of Facultad de Ciencias Naturales y Museo, Universidad Nacional de La Plata, Argentina; Project 05-G of Facultad de Ciencias Exactas y Naturales, Universidad Nacional de La Pampa, Argentina, and i-COOPB-20287 of Consejo Superior de Investigaciones Científicas de Cooperación Internacional. Finally, we are thankful for the comments and corrections made by the editors (M.E. Pérez, M. Arnal, and A.P. Carignano) and two anonymous reviewers, who greatly helped improve the manuscript.

\section{REFERENCES}

Álvarez, M.C., Kaufmann, C.A., Massigoge, A., Gutiérrez, M.A., Rafuse, D.J., Scheifler, N.A., and González, M.E. 2012. Bone modification and destruction patterns of leporid carcasses by Geoffroy's cat (Leopardus geoffroyi): an experimental study. Quaternary International 278: 71-80. Doi: doi.org/10.1016/j.quaint.2011.11.029

Andrade, A. 2015. Distinguishing between cultural and natural depositional agents: Micromammal taphonomy from the archaeological site Cueva y Paredón Loncomán (Patagonia, Argentina).
Journal of Archaeological Science: Reports 3: 122-131. Doi: doi.org/10.1016/j.jasrep.2015.06.012

Andrews, P. 1990. Ow/s, caves and fossils. Predation, preservation, and accumulation of small mammal bones in caves, with the analysis of the Pleistocene cave faunas from Westbury-sub-Mendip, Somerset, UK. Natural History Museum Publications, London, 231 p.

Andrews, P. 1995. Mammals as palaeocological indicators. Acta Zoologica Cracovensia 38: 59-72.

Bailon, S. 2011. La taphonomie des amphibiens et des reptiles squamates: état de la question. In: V. Laroulandie, J.-B. Mallye, and C. Denys (Eds.), Taphonomie des Petits Vertébrés: Référentiels et Transferts aux fossiles. British Archaeological Reports, International Series 2269, Oxford, p. 33-41.

Bochenski, Z.M. 2005. Owls, diurnal raptors and humans: signature on avian bones. In: T. O'Connor (Ed.), Biosfere to Lithosfere. New Studies in Vertebrate Taphonomy. Oxbow Books, Oxford, p. 31-45.

Bochenski, Z.M., Boev, Z., Mitev, I., and Tomek, T. 1993. Patterns of bird bone fragmentation in pellets of the Tawny Owl (Strix aluco) and the Eagle Owl (Bubo bubo) and their taphonomic implications. Acta Zoologica Cracoviense 36: 313-328.

Bochenski, Z.M., and Tomek, T. 1994. Pattern of bird bone fragmentation in pellets of the Long-eared Owl Asio otus and its taphonomic implications. Acta Zoologica Cracoviense 37: 177-190.

Bochenski, Z.M., Tomek, T., Tornberg, R., and Wertz, K. 2009. Distinguishing nonhuman predation on birds: pattern of damage done by the white-tailed eagle Haliaetus albicilla, with comments on the punctures made by the golden eagle Aquila chrysaetos. Journal of Archaeological Science 36: 122-129. Doi: doi.org/ 10.1016/j.jas.2008.07.018

Bochenski, Z.M., and Tornberg, R. 2003. Fragmentation and preservation of bones in uneaten food remains of the Gyrfalcon Falco rusticolus. Journal of Archaeological Science 30: 1665-1671. Doi: doi.org/10.1016/S0305-4403(03)00069-4

Broughton, J.M., Cannon, V.I., Arnold, S., Bogiatto, R.J., and Dalton, K. 2006. The taphonomy of owl-deposited fish remains and the origin of the Homestead Cave ichthyofauna. Journal of Taphonomy 4: 69-95.

Bruce, M.D. 1999. Family Tytonidae (Barn-Owls). In: J. del Hoyo, A. Elliott, and J. Sartagal (Eds.), Handbook of the birds of the world. Volume 5: Barn-owls to Hummingbirds. Lynx Editions, Barcelona, p. $34-75$.

Bruderer, C., and Denys, C. 1999. Inventaire taxonomique et taphonomique d'un assemblage de pelotes d'un site de nidification de T. alba de Mauritanie. Bonner Zoologische Beiträge 48: 245-257.

Campmas, E., Stoetzel, E., and Denys, C. 2018. African carnivores as taphonomic agents: contribution of modern coprogenic sample analysis to their identification. International Journal of Osteoarchaeology. Doi: doi.org/10.1002/oa.2650

Carrera, J.D., and Fernández, F.J. 2010. Análisis tafonómico de egagrópilas producidas por el lechuzón orejudo (Asio clamator): un caso experimental. In: M.A. Gutiérrez, M. De Nigris, P. Fernández, M. Giardina, A.F. Gil, A. Izeta, G. Neme, and H.D. Yacobaccio (Eds.), Zooarqueología a principios del siglo XXI: aportes teóricos, metodológicos y casos de estudio. Ediciones Libros del Espinillo, Buenos Aires, p. 381-386.

Castillo, C., Martín, E., and Coello, J.J. 2001. Small vertebrate taphonomy of La Cueva del Llano, a volcanic cave of Fuerteventura (Canary Islands, Spain). Palaeogeography, Palaeoclimatology, Palaeoecology 166: 277-291. Doi: doi.org/10.1016/S00310182(00)00213-3 
Cerdeño, E., and Bond, M. 1998. Taxonomic revision and phylogeny of the Pachyrukhinae, Notoungulata, from the Upper Miocene to the Pleistocene of Argentina. Journal of Vertebrate Paleontology 18: 799-811.

Cione, A.L., Gasparini, G.M., Soibelzon, E., Soibelzon, L.H., and Tonni, E.P. 2015. The Great American Biotic Interchange: A South American Perspective. Dordrecht, Springer, 97 p. Doi:10.1007/978-94017-9792-4

Crivelli-Montero, E., Pardiñas, U.F.J., Fernández, M., Bogazzi, M., Chauvin, A., Fernández, V., and Lezcano, M. 1996. La Cueva Epullán Grande (Provincia de Neuquén, Argentina). Informe de avance. Præhistoria 2: 185-240.

Cruz, I. 2008. Avian and mammalian bone taphonomy in southern continental Patagonia: A comparative approach. Quaternary International 180: 30-37. Doi: doi.org/10.1016/j.quaint.2007.08.008

Denys, C. 2011. Des référentiels en taphonomie des petits vertébrés: bilan et perspectives. In: V. Laroulandie, J.B. Mallye, and C. Denys (Eds.), Taphonomie des Petits vertébrés référentiels et transferts aux fossiles. British Archaeological Reports International Series 2269, Oxford, p. 7-22.

Denys, C., Dauphin, Y., Rzebik-Kowalska, B., and Kowalski, K. 1996. Taphonomic study of Algerian owl pellets assemblages and differential preservation of some rodents. Paleoecological implications. Acta Zoologica Cracoviensis 39: 103-116.

Denys, C., Stoetzel, E., Andrews, P., Bailon, S., Rihane, A., Huchet, J.B., Fernández-Jalvo, Y., and Laroulandie, V. 2018. Taphonomy of Small Predators multi-taxa accumulations: palaeoecological implications. Historical Biology 30: 868-881. Doi: doi.org/ 10.1080/ 08912963.2017 .1347647

Deschamps, C.M., Vucetich, M.G., Verzi, D.H., and Olivares, A.I. 2012. Biostratigraphy and correlation of the Monte Hermoso Formation (early Pliocene, Argentina): The evidence from caviomorph rodents. Journal of South American Earth Sciences 35: 1-9. Doi: doi.org/10.1016/j.jsames.2011.10.006

Dodson, P., and Wexlar, D. 1979. Taphonomic investigations of owl pellets. Paleobiology 5: 275-284. Doi: doi.org/10.1017/ S0094837300006564

Efremov, I.A. 1940. Taphonomy: new branch of paleontology. Pan American Geology 74: 81-93.

Esteban-Nadal, M., Cáceres, I., and Fosse, P. 2010. Characterization of a current coprogenic sample originated by Canis lupus as a tool for identifying a taphonomic agent. Journal of Archaeological Science 37: 2959-2970. Doi: 10.1016/j.jas.2010.06.033

Fernández, F.J. 2012. [Microvertebrados del Holoceno de sitios arqueológicos en el sur de Mendoza (República Argentina): aspectos tafonómicos y sus implicancias en la subsistencia humana. PhD Thesis, Facultad de Ciencias Naturales y Museo, Universidad Nacional de La Plata, La Plata, 518 p. Unpublished.].

Fernández, F.J., and De Santis, L.J.M. 2013. Tafonomía de restos de micromamíferos recuperados del sitio arqueológico Agua de La Mula (Mendoza, Argentina) y su implicancia en la subsistencia humana. Cuadernos del INAPAL, Series Especiales 1: 181-195.

Fernández, F.J., del Papa, L., Mange, E., Teta, P., Crivelli Montero, E., and Pardiñas, U.F.J. 2016a. Human subsistence and environmental stability during the last 2200 years in Epullán Chica cave (northwestern Patagonia, Argentina): a perspective from the zooarchaeological record. Quaternary International 391: 38-50. Doi: doi.org/10.1016/j.quaint.2015.06.013

Fernández, F.J., del Papa, L., Moreira, G., Prates, L., and De Santis, L.J.M. 2011. Small mammal remains recovered from two archaeological sites in the middle and lower Negro River valley
(Late Holocene, Argentina): taphonomic issues and paleoenvironmental implications. Quaternary International 245: 136-147. Doi: doi.org/10.1016/j.quaint.2010.12.027

Fernández, F.J., Hadler, P., Cherem, J.J., Saldanha, J.P., Stutz, N.S., Dias, A.S., and Pardiñas, U.F.J. 2019. Holocene small mammals hunted by owls and humans in southern Brazil: taphonomic evidence and biological significance. Boreas. Doi: doi.org/10.1111/ bor.12399.

Fernández, F.J., and Montalvo, C.I. 2017. Actualistic taphonomy of small mammals from owl pellets in South America and its archaeological implication. Global Journal of Archaeology \& Anthropology 2: 1-3.

Fernández, F.J., Montalvo, C.I., Fernández-Jalvo, Y., Andrews, P., and López, J.M. 2017. A re-evaluation of the taphonomic methodology for the study of small mammal fossil assemblages of South America. Quaternary Science Reviews 155: 37-49. Doi: dx.doi.org/ 10.1016/j.quascirev.2016.11.005

Fernández F.J., Moreira, G.J., Ballejo, F., and De Santis, L.J.M. $2009 \mathrm{~b}$. Novedosos registros de aves exhumadas del sitio arqueológico "Laguna El Sosneado (LS-3)" para el Holoceno tardío en el sur de Mendoza: aspectos tafonómicos. Intersecciones en Antropología 10: 327-342.

Fernández, F.J., Moreira, G.J. Neme, G.A., and De Santis, L.J.M. 2009a. Microvertebrados exhumados del sitio arqueológico «Cueva Arroyo Colorado» (Mendoza, Argentina): aspectos tafonómicos y significación paleoambiental. Archaeofauna 18: 99-118.

Fernández, F.J., Neme, G., and De Santis, L.J.M. 2015. Micromammals, taphonomy, paleoenvironments and human occupation during the Holocene in Arroyo Malo-3 (west-central Argentina). Archaeofauna 24: 27-52.

Fernández, F.J., and Pardiñas, U.F.J. 2018. Small mammals taphonomy and environmental evolution during Late Pleistocene-Holocene in Monte Desert: The evidence of Gruta del Indio (central west Argentina). Journal of South American Earth Sciences 84: 266-275. Doi: doi.org/10.1016/j.jsames.2018.04.012

Fernández, F.J., Teta, P., Barberena, R., and Pardiñas, U.F.J. 2012. Small mammal remains from Cueva Huenul 1, Argentina. Taphonomy and Paleoenvironments since the Late Pleistocene. Quaternary International 2078: 22-31. Doi:10.1016/ j.quaint.2012.01.005

Fernández, F.J., Teta, P., Mange, E., Prates, L., Gonzalez Venanzi, L., and Pardiñas, U.F.J. 2016b. Micromamíferos del sitio arqueológico Cueva Galpón (Río Negro, Argentina): aspectos tafonómicos y reconstrucción paleoambiental para el Holoceno tardío en Norpatagonia oriental. Revista de Arqueología 22: 105-124.

Fernández-Jalvo, Y., and Andrews, P. 1992. Small mammal taphonomy of Gran Dolina, Atapuerca (Burgos), Spain. Journal of Archaeological Science 19: 407-428. Doi: doi.org/10.1016/ 0305-4403(92)90058-B

Fernández-Jalvo, Y., Andrews, P., Denys, C., Sesé, C., Stoetzel, E., Marin-Monfort, D., and Pesquero, D. 2016. Taphonomy for taxonomists: implications of predation in small mammal studies. Quaternary Science Review 139: 138-157. Doi: doi.org/10.1016/ j.quascirev.2016.03.016

Fernández-Jalvo, Y., Andrews, P., Sevilla, P., and Requejo, V. 2014. Digestion versus abrasion features in rodent bones. Lethaia 47 : 323-336. Doi: 10.1111/let.12061

Galmes, M., Montalvo C.I., Santillán M.A., and Cereghetti J. 2015. Análisis de los restos óseos de vertebrados consumidos por el Águila Coronada (Buteogallus coronatus, Accipitriformes, Accipitridae) en La Pampa, Argentina. $16^{\circ}$ Reunión Argentina de Ornitología (La Plata), Abstracts: 88. 
Gómez, G.N. 2005. Analysis of bone modifications of Bubo virginianus' pellets from Argentina. Journal of Taphonomy 3: 1-16.

Gómez, G.N. 2007. Predators categorization based on taphonomic analysis of micromammals bones: a comparison to proposed models. In: M.A. Gutierrez, L. Miotti, G. Barrientos, G. Mengoni Goñalons, and M. Salemme (Eds.), Taphonomy and Zooarchaeology in Argentina. British Archaeological Reports British Series 1601, Archaeopress, Oxford, p. 89-103.

Gómez, G.N., and Kaufmann, C.A. 2007. Taphonomic analysis of Pseudalopex griseus (Gray, 1837). Scat assemblages and their archaeological implications. Journal of Taphonomy 5: 59-70.

Guillaud, E., Bearez, P., Denys, C., and Raimond, S. 2017. New data on fish diet and bone digestion of the Eurasian otter (Lutra lutra) (Mammalia: Mustelidae) in central France. The European Zoological Journal 84: 226-237.

Hadler, P., Cherem, J.J., Turbay, R., Alberti, A., and Pardiñas, U.F.J. 2016. Diversidade de pequenos mamíferos (Didelphimorphia e Rodentia) do Holoceno do Nordeste do Estado do Rio Grande do Sul, Brasil: implicações taxonômicas e paleoambientais. Revista brasileira de paleontologia 19: 126-144.

Hammer, $\varnothing$., Harper, D.A.T., Ryan, P.D. 2001. PAST: Paleontological statistics software package for education and data analysis. Palaeontologia Electronica 4: 9 p.

Hoffman, R. 1988. The contribution of raptorial birds to patterning in small mammal assemblages. Paleobiology 14: 81-90. Doi: doi.org/10.1017/S0094837300011817

Iglesias, A.C. 2009. [Tafonomía de pequeños vertebrados depredados por Buteo polyosoma (Aves, Falconiformes). Degree Thesis, Facultad de Ciencias Exactas y Naturales, Universidad Nacional de La Pampa, Santa Rosa, 66 p. Unpublished.].

Kerber, L., Negri, F.R., Ribeiro, A.M., Nasif, N., Pereira Souza-Filho, J., and Ferigolo, J. 2017. Tropical Fossil Caviomorph Rodents from the Southwestern Brazilian Amazonia in the Context of the South American Faunas: Systematics, Biochronology, and Paleobiogeography. Mammal Evolution 24: 57-70. Doi: 10.1007/ s10914-016-9340-2

Kusmer, K.C. 1990. Taphonomy of owl pellet deposition. Journal of Paleontology 64: 629-637.

Laudet, F., and Selva, N. 2005. Ravens as small mammal bone accumulators: First taphonomic study on mammal remains in raven pellets. Palaeogeography, Palaeoclimatology, Palaeoecology 226: 272-286.

Lloveras, LI. 2017. Los estudios neotafonómicos, una herramienta clave para valorar el papel del lince ibérico como agente acumulador en conjuntos osteoarqueológicos de conejo de la península ibérica. Interaccions entre felins i humans. III Jornades d'arqueozoologia. Museu de Prehistòria de València, Valencia, p. 113-133.

Lloveras, LI., Moreno-García, M., and Nadal, J. 2008. Taphonomic study of leporid remains accumulated by the Spanish Imperial Eagle (Aquila adalberti). Geobios 41: 91-100.

Lloveras, Ll., Moreno-García, M., and Nadal, J. 2009. The Eagle Owl (Bubo bubo) as a leporid remains accumulator. Taphonomic analysis of modern rabbit remains recovered from nests of this predator. International Journal of Osteoarchaeology 19: 573-592.

Lloveras, LI., Moreno-García, M., and Nadal, J. 2012. Assessing the variability in taphonomic studies of modern leporid remains from Eagle Owl (Bubo bubo) nest assemblages: the importance of age of prey. Journal of Archaeological Science 39: 3754-3764. Doi: doi.org/10.1016/j.jas.2012.06.033

Lloveras, LI., Thomas, R., Cosso, A., Pinyol, C., and Nadal, J. 2018.
When wildcats feed on rabbits: an experimental study to understand the taphonomic signature of European wildcats (Felis silvestris silvestris). Archaeological and Anthropological Sciences 10: 449-464. Doi: 10.1007/s12520-016-0364-6

López, J.M., Chiavazza, H., and Rosi, M.I. 2016. Small mammal remains recovered from two archaeological sites in northwestern Mendoza (late Holocene, Argentina): Taxonomic composition, taphonomic issues, and paleoenvironmental implications. Quaternary International 391: 26-37.

López, J.M., Fernández, F., Castillo, L., and Pereyra-Lobos, R. 2018. Taphonomy of small mammal bone accumulations generated by the Chaco owl (Strix chacoensis, Strigiformes) from the Monte Desert (Mendoza, Argentina): a contribution to South American archaeological and palaeontological studies. Boreas 47: 780-791. Doi: 10.1111/bor.12313

López, J.M., Fernández, F., Montalvo, C.I., Chiavazza, H., and De Santis, L.J.M. 2017a. The Role of the Accipitriforms Geranoaetus melanoleucus and Geranoaetus polyosoma as Small Mammal Bones Accumulator in modern and Archaeological Sites from Central Western Argentina. Journal of Taphonomy 15: 91-108.

López, J.M., Rosi, M.I., Tabeni, S., Bender, B., and Chiavazza, H. 2017b. Taphonomic analysis of small mammal bone remains preyed upon by wildcats (Carnivora: Felidae) from the central Monte Desert (Mendoza, Argentina). Boreas 43: 283-293. Doi: 10.1111/bor.12211

Marks, J.S., Cannings, R.J., and Mikkola, H. 1999. Family Strigidae (Typical Owls). In: J. del Hoyo, A. Elliott, and J. Sartagal (Eds.), Handbook of the birds of the world. Volume 5: Barn-owls to Hummingbirds. Lynx Editions, Barcelona, p. 76-242.

Matthews, T. 2006. Taphonomic characteristics of micromammals predated by small mammalian carnivores in South Africa: application to fossil accumulations. Journal of Taphonomy 4: 143-161.

Mellett, J.S. 1974. Scatological origin of microvertebrate fossil accumulations. Science 185: 349-350.

Mignino, J. 2017. [Zooarqueología de pequeños mamíferos en ocupaciones del Holoceno Tardio del sitio Alero Deodoro Roca (Valle de Ongamira, Córdoba). Degree Thesis, Facultad de Filosofía y Humanidades, Universidad Nacional de Córdoba, Córdoba, 90 p. Unpublished.].

Mignino, J., Izeta, A., and Cattáneo, R. 2018. Modern and archaeological owl pellets as paleoenvironmental and taphonomic markers in human occupation contexts in the Ongamira Valley, Córdoba, Argentina. Journal of Archaeological Science: Reports 18: 65-77. Doi: doi.org/10.1016/j.jasrep.2017.12.054.

Mondini, M. 2000. Tafonomía de abrigos rocosos de la Puna: formación de conjuntos escatológicos por zorros y sus implicaciones arqueológicas. Archaeofauna 9: 151-164.

Mondini, M. 2001. Taphonomic action of foxes in Puna rockshelters: a case study in Antofagasta de la Sierra (Province of Catamarca, Argentina). In: L.A. Kuznar (Ed.), Ethnoarchaeology of Andean South America: contributions to archaeological method and theory. International Monographs in Prehistory, Ethnoarchaeological Series 4, Berghahn Books Inc, New York, p. 266-295.

Mondini, M. 2012. Tafonomía de carnívoros en los Andes Centro- Sur: madrigueras actuales y sus implicaciones para el registro arqueofaunístico. In: A. Acosta, D. Loponte, L. Mucciolo (compilers). Temas de arqueología: estudios tafonómicos y zooarqueológicas (II). Asociación Amigos del Instituto Nacional de Antropología y Pensamiento Latinoamericano, Buenos Aires, p. 67-105.

Mondini, M. 2017. Carnivore taphonomy in South America: a review of actualistic studies and their implications in the southern Neotropics. Historical Biology 30: 774-785. Doi: doi.org/10.1080/ 
08912963.2017 .1319831

Mondini, M., and Muñoz, A.S. 2008. Pumas as taphonomic agents: a comparative analysis of actualistic studies in the Neotropics. Quaternary International 180: 52-62. Doi: doi.org/10.1016/ j.quaint.2007.08.013

Montalvo, C.I. 2004. [Paleobiología de la asociación faunística de Caleufú (La Pampa, Formación Cerro Azul, Mioceno superior-Plioceno inferior) a través de análisis tafonómicos. PhD. Thesis, Facultad de Ciencias Naturales y Museo, Universidad Nacional de La Plata, La Plata, 251 p. Unpublished.].

Montalvo, C.I., Bisceglia, S., Kin, M., and Sosa, R.A. 2012a. Taphonomic analysis of rodent bone accumulations produced by Geoffroy's cat (Leopardus geoffroyi, Carnivora, Felidae) in Central Argentina. Journal of Archaeological Science 39: 1933-1941. Doi: doi.org/10.1016/j.jas.2012.02.024

Montalvo, C.I., Fernández, F.J., Bargo, M.S., Tomassini, R.L., and Mehl, A. 2017. First record of a Late Holocene fauna associated with an ephemeral fluvial sequence in La Pampa Province, Argentina. Taphonomy and paleoenvironment. Journal of South America Earth Sciences 76: 225-237. Doi: dx.doi.org/10.1016/ j.jsames.2017.03.007

Montalvo, C.I., Fernández, F.J., Galmes, M., Santillán, M., and Cereghetti, J. 2016a. Crowned solitary eagle (Buteogallus coronatus) as accumulator of armadillos osteoderms in the archaeological record? An actualistic taphonomy study for Central Argentina. Quaternary International 391: 90-99. Doi: 10.1016/j.quaint.2015.08.017

Montalvo, C.I., Fernández, F.J., Liébana, M.S., Santillán, M., and Sarasola, J.H. 2014. Taphonomic analysis of rodent bone accumulations produced by the White-tailed Kite (Elanus leucurus, Accipitriformes) in Central Argentina. Journal of Archaeological Science 52: 354-362. Doi: doi.org/10.1016/j.jas.2014.09.003

Montalvo, C.I., Fernández, F.J., and Tallade, P.O. 2016b. The role of Bubo virginianus magellanicus as rodent bone accumulator in archaeological sites. A case study for the Atuel River (Mendoza, Argentina). International Journal of Osteoarchaeology 26: 974986. Doi: 10.1002/oa.2509

Montalvo, C.I., Melchor, R.N., Visconti, G., and Cerdeño, E. 2008a. Vertebrate taphonomy in loess-paleosol deposits: A case study from the Late Miocene of central Argentina. Geobios 41: 133-143. Doi: 10.1016/j.geobios.2006.09.004

Montalvo, C.I., Pessino, M.E, and Bagatto, F.C. 2008b. Taphonomy of the bones of rodents consumed by Andean hog-nosed skunks (Conepatus chinga, Carnivora, Mephitidae) in central Argentina. Journal of Archaeological Science 35: 1481-1488. Doi: doi.org/10.1016/j.jas.2007.02.012

Montalvo, C.I., Pessino, M., and González, V. 2007. Taphonomic analysis of remains of mammals eaten by pumas (Puma concolor Carnivora, Felidae) in central Argentina. Journal of Archaeological Science 34: 2151-2160. Doi:10.1016/j.jas.2007.02.012

Montalvo, C.I., and Tallade, P. 2009. Taphonomy of the accumulations produced by Caracara plancus (Falconidae). Analysis of prey remains and pellets. Journal of Taphonomy 7: 235-248.

Montalvo, C.I., and Tallade, P.O. 2010. Análisis tafonómico de restos no ingeridos de roedores presa de Caracara plancus (Aves, Falconidae). In: M. De Nigris, P.M. Fernández, M. Giardina, A.F. Gil, M.A. Gutiérrez, A. Izeta, G. Neme, and H.D. Yacobaccio (Eds.), Zooarqueología a principios del siglo XXI: aportes teóricos, metodológicos y casos de estudio. Ediciones Libros del Espinillo, Buenos Aires, p. 419-428.

Montalvo, C.I., Tallade, P., Fernández, F.J., Moreira, G., Rafuse, D., and De Santis, L. 2011. Bone damage patterns found in the avian prey remains of crested Caracara Caracara plancus (Aves,
Falconiformes). Journal of Archaeological Science 38: 3541-3548. Doi: doi.org/10.1016/j.jas.2011.08.021

Montalvo, C.I., and Tejerina, P. 2009. Análisis tafonómico de los huesos de anfibios y roedores depredados por Athene cunicularia (Strigiformes, Strigidae) en La Pampa, Argentina. In: M. Berón, L. Luna, M. Bonomo, C.I. Montalvo, C. Aranda, and M. Carrera Aizpitarte (Eds.), Mamül Mapu: pasado y presente desde la arqueología pampeana 1. Editorial Libros del Espinillo, Buenos Aires, p. 323-334.

Montalvo, C.I., Tomassini, R.L., and Sostillo, R. 2016c. Leftover prey remains: a new taphonomic mode from the late Miocene (Cerro Azul Formation) in central Argentina. Lethaia 49: 219-230. Doi: 10.1111/let.12140

Montalvo, C.I., Tomassini, R., Visconti, G., and Tiranti, S. 2012b. Análisis tafonómico de micromamíferos del Pleistoceno Superior del Quequén Salado, provincia de Buenos Aires, Argentina. Revista brasileira de paleontologia 15: 345-358.

Montalvo, C.I., Vezzosi, R.I, and Kin, M.S. 2015. Taphonomic analysis of rodent bones from Lontra longicaudis (Mustelidae, Carnivora) scats in fluvial environments. Mastozoología Neotropical 22: 319-333.

Nasif, N.L., Esteban G.I., and Ortiz, P.E. 2009. Novedoso hallazgo de egagrópilas en el Mioceno tardío, Formación Andalhuala, provincia de Catamarca, Argentina. Serie Correlación Geológica 25: 105-114.

Ortiz, P.E. 2001. [Roedores del Pleistoceno superior del Valle de Tafí (provincia de Tucumán), implicancias paleoambientales y paleobiogeográficas. PhD Thesis, Facultad de Ciencias Naturales e Instituto Miguel Lillo, Universidad Nacional de Tucumán, 230 p. Unpublished.].

Ortiz, P.E., and Jayat, P. 2007. Roedores sigmodontinos (Mammalia: Rodentia: Cricetidae) del límite Pleistoceno-Holoceno en el valle de Tafí (Tucumán, Argentina): taxonomía, tafonomía y significación paleoambiental. Ameghiniana 44: 641-660.

Ortiz, P.E., and Pardiñas, U.F.J. 2001. Sigmodontinos (Mammalia, Rodentia) del Pleistoceno tardío del valle de Tafi (Tucumán, Argentina): taxonomia, tafonomía y reconstrucción paleoambiental. Ameghiniana 38: 3-26.

Pardiñas, U.F.J. 1996-1998. Roedores holocénicos del sitio Cerro Casa de Piedra 5 (Santa Cruz, Argentina): tafonomía y paleoambientes. Palimpsesto. Revista de Arqueología 5: 66-90.

Pardiñas, U.F.J. 1999a. [Los roedores muroideos del Pleistoceno Tardío-Holoceno en la Región Pampeana (sector este) y Patagonia (República Argentina): aspectos taxonómicos, importancia bioestratigráficas y significación paleoambiental. PhD Thesis, Facultad de Ciencias Naturales y Museo, Universidad Nacional La Plata, La Plata, 283 p. Unpublished.].

Pardiñas, U.F.J. 1999b. Tafonomía de microvertebrados en yacimientos arqueológicos de Patagonia. Arqueología 9: 265-308.

Pardiñas, U.F.J. 2004. Roedores sigmodontinos (Mammalia: Rodentia: (ricetidae) y otros micromamíferos como indicadores de ambientes hacia el Ensenadense cuspidal en el sudeste de la provincia de Buenos Aires (Argentina). Ameghiniana 41: 437-450.

Pardiñas, U.F.J., and Galliari, C.A. 1998. Sigmodontinos (Rodentia, Muridae) del Holoceno inferior de Bolivia. Revista Española de Paleontología 13: 17-25.

Pardiñas, U.F.J., D’Elía G., and Ortiz, P.E. 2002. Sigmodontinos fósiles (Rodentia, Muroidea, Sigmodontinae) de América del Sur: estado actual de su conocimiento y prospectiva. Mastozoología Neotropical 9: 209-252.

Pardiñas, U.F.J., Moreira, G., García-Esponda, C., and De Santis, L.M.J. 2000. Deterioro ambiental y micromamíferos durante el Holo- 
ceno en el nordeste de la estepa patagónica (Argentina). Revista Chilena de Historia Natural 72: 541-556.

Pinto Llona, A., and Andrews, P. 1999. Amphibian taphonomy and its application to the fossil record of Dolina (middle Pleistocene, Atapuerca, Spain). Palaeogeography. Palaeoclimatology. Palaeoecology 149: 411-429. Doi: doi.org/10.1016/S0031-0182(98) 00215-6

Pokines, J.T. 2014. Mammalian Microfaunal Remains from Khonkho Wankane (Late Formative Period), Mollo Kontu (Middle Horizon Period) and Pukara de Khonkho (Late Intermediate Period) in the Bolivian Altiplano. International Journal of Osteoarchaeology 24: 505-516. Doi: doi.org/10.1002/oa.2237

Pokines, J.T., and Kerbis Peterhans, J.C. 1997. Barn owl (Tyto alba) taphonomy in the Negev desert, Israel. Israel Journal of Zoology 43: 19-27. Doi: 10.1080/00212210.1998.10688930

Quintana, C. 2001. Composición y cambios en la secuencia faunística. In: A. Mazzanti, and C. Quintana (Eds.), Cueva Tixi: cazadores y recolectores de las sierras de Tandilia oriental. I. Geología, Paleontología y Zooarqueología. Publicación Especial 1. Laboratorio de Arqueología, Universidad Nacional de Mar del Plata, Mar del Plata, p. 37-64.

Quintana, C. 2015. Tafonomía de contenidos dispersos de egagrópilas de Tyto alba en un ambiente serrano. Historia Natural 5: 29-47.

Quintana, C. 2016a. Tafonomía de los microvertebrados del sitio arqueológico Cueva Tixi (Pleistoceno tardío-Holoceno tardío), Tandilia oriental (provincia de Buenos Aires, Argentina). Publicación Electrónica de la Asociación Paleontológica Argentina 16: 14-51.

Quintana, C. 2016b. Microvertebrados del sitio arqueológico Cueva El Abra, Tandilia Oriental: tafonomía y paleoambiente. Comechingonia 20: 203-229.

Reed, D.N. 2005. Taphonomic implications of roosting behavior and trophic habits in two species of African owl. Journal of Archaeological Science 32: 1669-1676. Doi: doi.org/10.1016/ j.jas.2005.05.007

Redford, K.H., and Eisenberg, J.F. 1992. Mammals of the Neotropics, volume 2. The Southern Cone: Chile, Argentina, Uruguay, Paraguay. University of Chicago Press, Chicago, 460 p.

Rodrigues, P.H. 2008. [Didelphimorphia, Chiroptera e Rodentia (Mammalia) do Holoceno do Estado do Rio Grande do Sul, Brasil: Aspectos taxonômicos, paleoambientais e paleoclimáticos. PhD Thesis, Programa de Pós-Graduação em Geociências, Universidade Federal do Rio Grande do Sul, 203 p. Unpublished.].

Royer, A., Montuire, S., Gilg, O., and Laroulandie, V. 2019. A taphonomic investigation of small vertebrate accumulations produced by the snowy owl (Bubo scandiacus) and its implications for fossil studies. Palaeogeography, Palaeoclimatology, Palaeoecology 514: 189-205. Doi: doi.org/10.1016/j.palaeo.2018.10.018

Rudzik, S.M., Fernández, F.J., and Carrera, D.J.D. 2015. Taphonomic Analysis of Micromammal Remains from Striped Owl (Pseudoscops clamator) Pellets in Northeastern Buenos Aires Province, Argentina: Implications for Archaeological Sites Formation. International Journal of Osteoarchaeology 25: 550-563. Doi: 10.1002/oa.2327

Russ, $H_{\text {., }}$ and Jones, A. 2011. Fish remains in cave deposits; how did they get there?. Cave and Karst Science 38: 57-60.

Saavedra, B. 1994. Tafonomía de micromamíferos de Chile central. $2^{\circ}$ taller de Arqueología de Chile Central (Santiago de Chile), Actas 1: 1-22.

Saavedra, B., and Simonetti, J.A. 1998. Small mammals taphonomy: Intraspecific bone assemblage comparison between South and North American Barn Owl, Tyto alba, populations. Journal of Archaeological Science 25: 165-170. Doi: doi.org/10.1006/ jasc.1997.0211

Saavedra, B., and Simonetti, J.A. 2003. Holocene distribution of Octodontid in central Chile. Revista Chilena de Historia Natural 76: 383-389.

Salemme, M., Escosteguy, P., and Frontini, R. 2012. La fauna de porte menor en sitios arqueológicos de la región pampeana, Argentina. Agente disturbador vs. recurso económico. Archaeofauna 21: 153-185.

Scheifler, N.A., Teta, P., and Pardiñas, U.F.J. 2012. Small mammals (Didelphimorphia and Rodentia) of the archaeological site Calera (Pampean region, Buenos Aires Province, Argentina): Taphonomic history and Late Holocene environments. Quaternary International 278: 32-44. Doi: doi.org/10.1016/j.quaint.2012.02.001

Scheifler, N.A., Messineo, P., and Pardiñas, U.F.J. 2015. Implicancias tafonómicas y paleoambientales de los pequeños vertebrados del sitio arqueológico Campo Laborde (centro de los pastizales pampeanos, Buenos Aires, Argentina). Archaeofauna 24: 187-208.

Simonetti, J.A., and Cornejo, L.E. 1991. Archaeological evidence of rodent consumption in central Chile. Latin American Antiquity 2: 92-96.

Sostillo, R., Cerdeño, E., and Montalvo, C.I. 2018. Taxonomic implications of a large sample of Tremacyllus (Hegetotheriidae: Pachyrukhinae) from the late Miocene Cerro Azul Formation of La Pampa, Argentina. Ameghiniana 55: 407-422.

Southern, H.N. 1954. Tawny owls and their prey. Ibis 96: 348-410. Souttou, K., Manaa, A., Stoetzel, E., Sekour, M., Hamani, A., Doumandji, S., and Denys, C. 2012. Small mammal bone modifications in black- shouldered kite Elanus caeruleus pellets from Algeria: implications for archaeological sites. Journal of Taphonomy 10: 1-19.

Stoetzel, E. 2009. [Les microvertebres du site d'occupation humained' El Harhoura 2 (Pleistocene superieur-Holocene, Maroc): systematique, evolution, taphonomie et paleoecologie. PhD Thesis, Museum national d'Histoire Naturelle, Paris, 432 p. Unpublished.].

Stutz, N.S., Cherem, J.J., Pardiñas, U.F.J., and Hadler, P. 2017. Roedores sigmodontíneos (Mammalia, Rodentia, Cricetidae) holocênicos do Rio Grande do Sul, Brasil - o sítio RS-TQ-58: Afonso Garivaldino Rodrigues. Revista brasileira de paleontologia 20: 133-148.

Tambussi, C., and Degrange, F. 2013. South American and Antarctic Continental Cenozoic Birds. Paleobiogeographic Affinities and Disparities. Springer Briefs in Earth System Sciences, Springer Netherlands, 113 p. Doi: 10.1007/978-94-007-5467-6

Terry, R.C. 2004. Owl pellet taphonomy: a preliminary study of the post-regurgitation taphonomic history of pellets in a temperate forest. Palaios 19: 497-506. Doi: doi.org/10.1669/08831351(2004)019\%3C0497:OPTAPS\%3E2.0.CO;2

Thiollay, J.M. 1994. Family Accipitridae (Hawks and Eagles). In: J. del Hoyo, A. Elliott, and J. Sartagal, (Eds.), Handbook of the birds of the world. Volume 2: New World vultures to Guinea Fowl. Lynx Editions, Barcelona, p.52-205.

Tomassini, R.L., and Montalvo, C.I. 2010. Coprolitos en la Formación Monte Hermoso, (Mioceno tardío-Plioceno temprano), Farola Monte Hermoso, Buenos Aires, Argentina. Ameghiniana 47: 111-115.

Tomassini, R.L., Montalvo, C.I., Beilinson, E., Deschamps, C.M., Garrone, M.C., Gasparini, G.M., Zárate, M.A., Rabassa, J., Ruella, A., and Tonni, E.P. 2017. Microvertebrates preserved in mammal burrows from the Holocene of the Argentine Pampas: a taphonomic and paleoecological approach. Historical Biology 29: 63-75. Doi: dx.doi.org/10.1080/08912963.2015.1124873

Torres, J., Teta, P., Filippi, V., Owen, R.D., and Pardiñas, U.F.J. 2015. First fossil record of sigmodontine rodents (Mammalia, Criceti- 
dae) for Paraguay: taxonomy and Late Pleistocene environments. Ameghiniana 52: 574-581.

Verzi, D.H., Montalvo, C.I., and Deschamps, C.M. 2008. Biostratigraphy and biochronology of the Late Miocene of central Argentina: Evidence from rodents and taphonomy. Geobios 41: 145-155. Doi: doi.org/10.1016/j.geobios.2006.09.005

White, C.M., Olsen, P.D., and Kiff, L.F. 1994. Family Falconidae (Falcons and Caracaras). In: J. del Hoyo, A. Elliott, and J. Sartagal (Eds.), Handbook of the birds of the world. Volume 2: New World vultures to Guinea Fowl. Lynx Editions, Barcelona, p. 216-275.

Wilson, D., and Reeder, D. (Eds.). 2005. Mammal Species of the World. Johns Hopkins University Press, Baltimore, 2 vol., 2142 p.

Doi: 10.5710/PEAPA.11.03.2019.275

Recibido: 13 de octubre de 2018

Aceptado: 11 de marzo de 2019 